\title{
Covid-19 Pandemic Process Experiences of the Healthcare Professional Mothers with Children with Special Needs*
}

\author{
Kübra DEMIRÖZ ${ }^{\mathrm{a}}$ (ORCID ID - 0000-0002-6054-0901) \\ Şeyda YILDIRIM PARLAK ${ }^{\text {b }}$ (ORCID ID - 0000-0002-1139-2447) \\ Sevim KÜçÜK KARAHAN ${ }^{c}$ (ORCID ID - 0000-0001-7753-4105) \\ Nilay KAYHAN ${ }^{\mathrm{d}^{*}}$ (ORCID ID - 0000-0002-0937-8013) \\ a,b,c,d Hasan Kalyoncu Üniversitesi, Eğitim Fakültesi, Özel Eğitim Bölümü, Gaziantep/ Türkiye \\ ${ }^{d}$ Ege Üniversitesi Eğitim Fakültesi Özel Eğitim Bölümü, Bornova, İzmir
}

CrossMark

\section{Article Info}

DOI: 10.14812/cufej.847347

Article history:

Received 28.12.20

Revised 17.05.21

Accepted $\quad 08.10 .21$

Keywords:

Healthcare professional,

Coronavirus (Covid-19),

Mother, Family,

Child with special needs.

\begin{abstract}
Children frequently spend time with their parents who are the primary caregivers in early childhood period. Some factors such as working conditions, cooperation level with the institution they receive service from, teachers responsible for education, and the intra-family patterns affect the motivation of parents who take various roles in supporting development of their children in this process. Parents working in the health field need support to meet the needs of their children. The participant group of the study in which phenomenologic desing, a qualitative method, was used consists of six (6) health worker mothers whose children attend the Metropolitan Municipality Barrier-Free Life Center and special education rehabilitation centers located in a city center in the Southeastern Anatolia Region. Data obtained were analyzed with content analysis method; 5 main themes and 27 sub-themes were obtained. According to findings of this study based on working life experiences of healthcare professional mothers, it draws attention that pandemic process has affected intra-family patterns. They stated they need support for care, health, and educational arrangements of children with special needs; emphasized the regulations based on family integrity, especially in terms of education and care. Suggestions to the authorities of the institutions based on the results of this study: Managers at work, teachers, and principals at school can plan processes that will provide the participation of the parents in education.
\end{abstract}

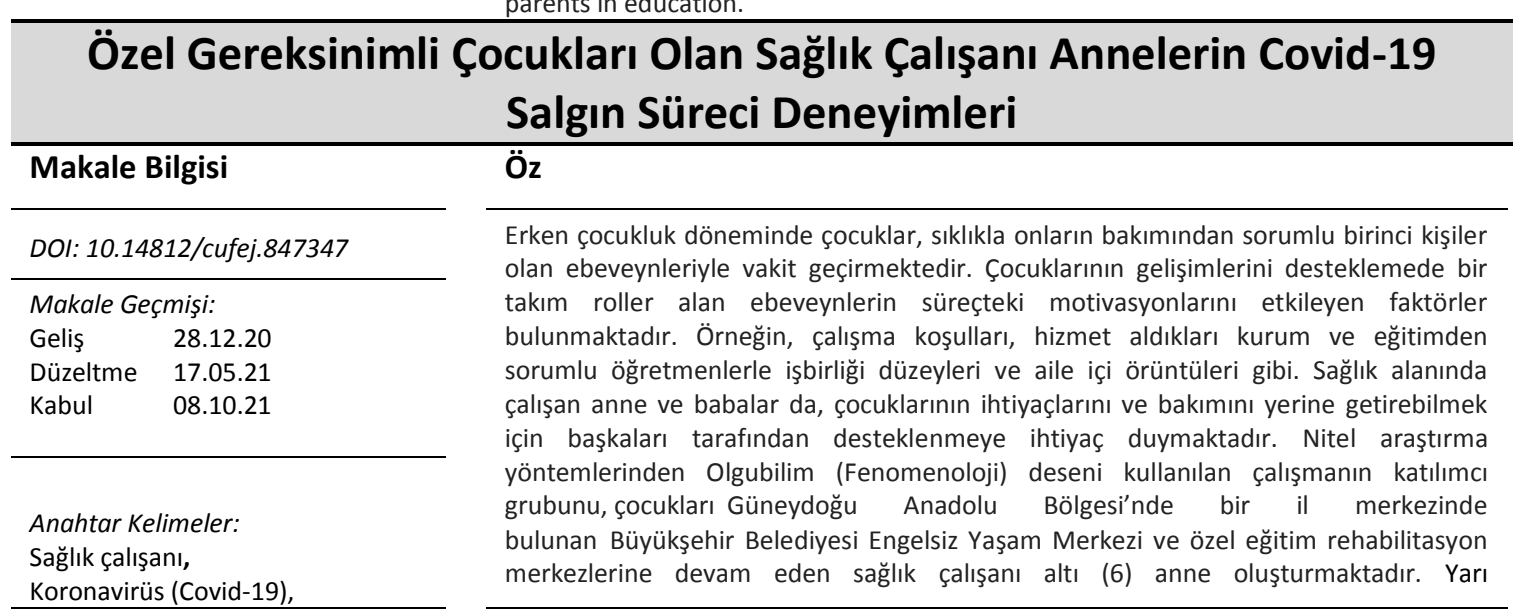


Anne,Aile,

Özel gereksinimli çocuk.

d*Author: nilaykayhan@gmail.com yapılandırılmış görüşme tekniği kullanılarak toplanan veriler içerik analizi ile değerlendirilmiş; 5 ana tema ve 27 alt tema elde edilmiştir. Sağlık çalışanı annelerin pandemi boyunca iş yaşamı deneyimlerinin temel alındığı bu araştırmanın bulgularına göre pandemi sürecinin aile içi örüntüleri etkilediği dikkati çekmiştir. Özel gereksinimli çocuklarının bakım, sağlık, eğitim düzenlemelerinde bir takım desteklere gereksinimleri olduğunu belirtmişler, bu konuda özellikle eğitim ve bakım açısından aile bütünlüğünü temel alan düzenlemelere vurgu yapmışlardır. Bu araştırmanın sonuçlarına dayalı olarak kurum yetkililerine yönelik öneriler: İş yerinde idareciler, okulda öğretmenler ve müdürler öğrenci velilerinin eğitime katılımını sağlayıcı olumlu destek süreçleri planlayabilirler.

\section{Introduction}

The early childhood period that covers the first years of life is a critical period in which the development of children is quite rapid. This period is the base for the cognitive, language, academic and social development of the children. Communication and experiences of the children with the family and social environment are significant. Children frequently spend time with their parents, the primary caregivers in the early childhood period. Thus, children gain the knowledge, skills, and experiences that they will use in the future through their experiences with their parents most in these years that start with birth (McDuffie \& Yoder, 2010). Parents', especially mother's interaction with the child takes an important place in the development of the child (Mahoney \& MacDonald, 2004). Consequently, the family has highly significant responsibilities in this period because the development is rapid and the children are open to learning (Birkan, 2001).

The first years in which the development of the individual is rapid are considered highly important and the characteristics of the children are significant for the care and education services provided in these years. Children with special needs have various needs in development areas such as language, cognitive, physical, social, academic, self-care. Accordingly, the early childhood period has a more critical importance for children with special needs. They need some arrangements in the behaviors they show; they need some different arrangements in the learning and communication process than their peers who show normal development due to different reasons. For example, children with autism spectrum disorder need more systematic teaching than their peers who show typical development to support their skill and behavior achievements (Orum-Çattık, Yetkin \& Diken, 2019). In terms of the acquisition of positive behavior, the importance of the interventions to eliminate problem behaviors emerges. At this point, families apply to special education services to meet the educational needs of their children. Early intervention studies, based on the early childhood period, are whole services regarding the needs of the children at young ages and their families in health, social, and education areas (Howard, Williams \& Leper, 2010). While the interventions in this period are significant for the independent life skills of the young children with disabilities in different areas in the following years, they also impose some responsibilities on the parents (Kanık, 1993). The parents can provide a little child with normal development with a lot of knowledge and skills naturally in daily life. However, it is more difficult for parents who have children with special needs to provide this knowledge and skills (Orum-Çattık, Yetkin \& Diken, 2019). In this situation, it becomes prominent to support the child and the family as a whole to support their children's development. It is also thought necessary to support parents about how they will support education and development of the children with special needs starting from the early childhood period (Cited by Munson \& Odom, 1996). Thus, qualified and continuous studies based on cooperation with the parents and family members are needed for the development of children with special needs. Therefore, it is thought significant to reveal and support the quality of the interaction between children with special needs and their parents, and increase the positive communication.

Some factors affect the motivation of the parents who take various roles in supporting the development of their children in this process. Working conditions, cooperation level with the institutions they receive service from, and the teachers responsible for education are among these variables. While the quality of these variables affects the family patterns, the mother-father-child 
relationship and attitudes of parents are also regarded as the determiners of the process (Demirbilek, 2013; Özbey, 2010; Toker, Başgül \& Özaydın, 2019). All these factors are related to the child's age of diagnosis, quality of education services that she/he receives, family participation, and time planning. Parents also take the responsibilities related to home and work life besides the responsibilities of the children with special needs. Especially working parents go through a difficult process to prepare their children with special needs for life better and meet their needs on one hand, they struggle against the difficulties brought by work-life on the other hand (Karadağ, 2014). When examining some studies on the difficulties experienced by the parents who have children with special needs, it has been stated that mothers are affected by working life, they compromise on themselves between child care and work life, they have difficulty in planning the working hours with their managers and colleagues, they do not know their legal rights or cannot use them, they experience a more difficult working life than the parents of the children with normal development (Hodgetts, McConnell \& Zwaigenbaum, 2014; Yassıbaş, 2015; Yıldırım \& Hacıfazlığlu, 2019). These results in the literature reveal the difficulties experienced by the parents in taking care of the children outside of their working life, highlight that they have some certain needs. These needs differ according to the parents' field of work; thus, the time spared by the parents for their children with special needs differs due to the difficulties that the parents experience in working life. It is important to examine the working conditions of the parents specific to the profession and examine the time they spare for their children with special needs, roles they take in their education, and their social development. Covid-19 pandemic, effects of which are felt in the whole world and which also affects the areas such as education, health, social life, economy, tourism has arisen in our country as of March 2020. It draws attention that the workload of the healthcare professionals has increased in the pandemic process in our country as in other countries; healthcare professionals needed some support for themselves and their families (izci, 2020). Coronavirus pandemic has affected especially the working and daily lives of healthcare professionals, caused changes in working hours and working units. The household routines of the healthcare professionals have been extremely affected as a result of the changes in the working units and working hours; their frequency of spending time with their families and children has decreased due to the increasing workload. It draws attention that especially female healthcare professionals, who make up a great majority of health workers, needed different support resources to balance their home lives while providing services for the health and lives of the patients in this process. Besides the changes in the working conditions of the mothers in this process, their responsibilities at home also increased and this made their burden heavier (Seven, 2020; United Nations International Children's Fund [UNICEF], 2020c; Zeybekoğlu-Akbaş \& Dursun, 2020). The process has become more tiring for the healthcare professional mothers whose responsibilities have increased with Coronavirus (Covid-19) and their children. Changing life conditions and increasing workload due to Covid-19 have been added to the mothers' responsibilities regarding the housework and their children. While the workload of the healthcare professionals often causes a challenging process for their home and family relationships even in the normal process, the increasing workload in the pandemic process has brought some difficulties (Baki \& Piyal, 2020). Panic and anxiety have been observed more intensely on the healthcare professionals and their families in the pandemic process due to the risky working conditions (Amakiri et.al, 2020). Working mothers who have children with psychologically typical development experience work and family conflict. However, apart from working life, the responsibilities of the mothers have increased due to the differences in the education and support needs of their children with special needs, they experienced the Covid-19 period with a different picture by being included in the working life in a risky pandemic process and with the responsibilities of home and their children. In this sense, the studies that examine the experiences of the healthcare professional mothers directly with their perspective and based on their perception, that examine how they go through the pandemic process according to their working conditions have been thought significant. While the literature includes that the working mothers experienced difficulties in balancing the work and life even in the normal process (Yıldırım \& Hacıfazlıoğlu, 2019); social changes in pandemic process and practices in the working life caused difficulties for mothers in balancing the home life and presented them with some difficulties. Therefore, working mothers have the role of sharing the responsibilities regarding their children in health, education processes with their partners and family members beside home and 
Demiröz, Yıldırım Parlak, Küçük Karahan \& Kayhan - Çukurova Üniversitesi Eğitim Fakültesi Dergisi, 50(2), 2021, 749-777

working life routines. These responsibilities of working mothers have increased in the pandemic process as the physical contact decreased, restrictions continued, and they could not receive support for the home life from a different assistant. As a result of all these, the social, home, and family lives of healthcare professionals were restricted; the time they spare for themselves and their family decreased (Zeybekoğlu-Akbaş \& Dursun).

Healthcare professionals have been more at risk due to their professional duties during Coronavirus (Covid-19) process, this situation has become a cause for anxiety independently (Çetintepe \& ilhan, 2020). Being at risk due to their profession led to a limited time spared for their responsibilities, children, partners, and close environment, and as a result, some emotional burdens have been added to the healthcare professionals besides their workload. The healthcare personnel felt more helpless as a result of these emotional burdens and had to deal with more intense anxiety (Huremović, 2019). When all these factors are combined, mothers have been exposed to more intense anxiety in terms of their responsibilities in the family, and the roles they take in their children's processes such as health, education, care, and social adaptation. Besides, schools and kindergartens were closed during the pandemic period, this made the process more complicated for working mothers. While mothers had to deal with anxiety due to the risks in work and social life on one hand, they tried to fulfill their roles regarding their responsibilities at home, health, and education of their children on the other hand (UNICEF, 2020a). These experiences also affected healthcare professional parents who have children with special needs negatively. While parents who have children with special needs allocated most of their time at home for their children's needs and supported them in accordance with their area of needs in the pre-pandemic period; the fact that the kindergartens, preschools, and centers where they received special education support were closed for precaution, and the fact that the caregivers could not continue support process at home for precautionary purposes have affected the families and the children with special needs negatively in the pandemic process. Arrangements must be made in the new period for the parents who work in the healthcare field and they need to be supported by others for the needs and care of their children to get out of the process with the least level of burnout and to be able to meet the education and care needs of their children (UNICEF, 2020a).

As a result, knowing what the families have gone through during the Coronavirus period is related to what kind of needs they may have in the new normal period. It is thought especially significant for determining what kind of support working mothers need both in the Coronavirus period and in the process of returning to normal. These needs must be taken into account in the arrangements that will be made. Thus, to draw attention to the working conditions of healthcare professional mothers who have children with special needs and to make life easier for them in the pandemic process, a necessity to examine their experiences regarding their work and family environment has arisen. This study, which is planned based on this need, aims to examine the experiences of the healthcare professional mothers who have children with special needs in the Coronavirus (Covid-19) pandemic process. The answers for the questions below have been sought in the study:

1- What do the healthcare professional mothers think about the effect of the Coronavirus (Covid19) process on the lives of their children with special needs, themselves, and family members?

2- What do the healthcare professional mothers think and suggest regarding arrangements for the work, home, and social life in the new normal process as a result of their experiences in the Coronavirus (Covid-19)?

\section{Method}

This chapter of the study includes the information about the study design, participants, and information about the researchers, demographic information, data collection instrument, data collection, and analysis. 


\section{Research Model}

This study was designed in phenomenological method, a qualitative research method, to determine the experiences of the healthcare professional parents who have children with special needs in the Covid-19 pandemic process. The phenomenological method is a design that defines the essence of individuals' experiences and describes their life experiences thoroughly. The focus is on "what" and "how" they experience while describing thoroughly (Creswell, 2016). Semi-structured interview technique was used in the questions asked to the participant mothers to provide flexibility in thorough data collection in the study; interviews were made with the healthcare professional mothers who have children with special needs regarding their experiences for this purpose.

\section{Study Group}

The participants of the study consist of six healthcare professional mothers whose children attend to Metropolitan Municipality Barrier-Free Life Center and special education rehabilitation centers in a city center in the South-eastern Anatolia Region. First of all, the principals of the centers and institutions were contacted through telephone or in the online environment. The purpose of the researchers was explained in the interviews and necessary permissions were taken. Then, the mothers were reached via institution principals and telephone interviews were conducted. In these interviews, explanations were made about the purpose and ethical rules (such as how to address the participant groups, the privacy of the information to be given, the data obtained will not be used for a different purpose other than this study, consent forms and interviews will be recorded as voice with the approval of participants). It is also explained that the questions that are asked in the research process do not have a correct or incorrect answer; their approval for voluntary participation was received. It was emphasized that they have a right to withdraw from the research at any stage of the research if they want. The demographic information regarding the mothers and children with special needs was included in Table 1.

Table 1.

The Demographic Information of the Children and Their Mothers

\begin{tabular}{|c|c|c|c|c|c|c|c|c|c|}
\hline \multicolumn{4}{|c|}{ Characteristics of the Mothers } & \multicolumn{6}{|c|}{ Characteristics of the Children with SN } \\
\hline Person & Code Nam & Age & Profession & Education Work & hours & Age & GenderL & iagnos & is Child care \\
\hline Mother1 & Fatma & 38 & $\begin{array}{c}\text { Nurse } \\
\text { (administrative) }\end{array}$ & Undergraduate & Flexible & 4 & Boy & DS & $\begin{array}{l}\text { Father's } \\
\text { support }\end{array}$ \\
\hline Mother2 & Su & 35 & Nurse (112) & Graduate & Intense & 5.5 & Girl & ASD & Baby-sitter \\
\hline Mother3 & Rüya & 35 & $\begin{array}{c}\text { Nurse } \\
\text { (Emergency) }\end{array}$ & Undergraduate & Flexible & 8 & Boy & ASD & $\begin{array}{l}\text { Father's } \\
\text { support }\end{array}$ \\
\hline Mother4 & Emine & 30 & Biologist & Undergraduate & Flexible & 2 & Girl & DS & Family Elde \\
\hline Mother5 & Hülya & 38 & Nurse & Undergraduate & Flexible & 7.5 & Girl & MD & Edu. Assist. \\
\hline Mother6 & Gamze & 37 & Purchasing M. & Undergraduate & Flexible & 7 & Boy & ASD & $\begin{array}{l}\text { Father's } \\
\text { support }\end{array}$ \\
\hline
\end{tabular}

As stated in Table 1, the six mothers who form the participant group are between the ages of 30 (Emine) and 38 (Fatma and Hülya), and 4 of them work as nurses (Fatma, Su, Rüya, Hülya). One of the mothers has a graduate degree (Su), others have an undergraduate degree. When examining the working hours, all mothers except Su who works as a 112-Emergency Nurse continue to work in the flexible working model; they take care of their children with the support of family elders and the fathers by working by turns (Fatma, Rüya, and Gamze). Mothers' children with special needs are between the ages of two and eight; Su, Rüya, and Gamze's children have Autism Spectrum Disorder (ASD) diagnosis; Fatma and Emine's children have Down's Syndrome, Hülya's daughter has Mental Disability diagnosis. 


\section{Researchers}

Planning this research, creating data collection instruments, determining the participants, obtaining permissions, interviews, data collection process, analysis and turning the data into findings and final reporting were carried out by a faculty member and three instructors. One of the researchers is a faculty member who has a doctoral degree in the special education field. The first author is at the master's degree dissertation stage, the second and third authors continue doctorate education. The professional seniority of the authors who contributed to the study differs between 3-20 years. The study was planned based on the experiences of the families about their children's education as well as the fact that the education institutions suspended face-to-face education and continued online education at home in the pandemic period. The steps of the study that is based on the experiences of the healthcare professionals especially regarding the workload and changes in the working hours are as follows:

A national and international literature review was conducted on the Coronavirus pandemic at the end of February 2020 and in March; legal regulations regarding the education, health, and social life in our country were examined. Researchers' distribution of tasks is as follows: All researchers worked on the literature review; the first three authors took responsibilities in conducting interviews, data collection, transferring the data to computer environment, and analysis. Faculty member, the fourth author of the study, took part in the literature review, determining the subject, method, and content in accordance with the need for the research, preparing the interview form, analysis of the data, turning the data into findings; and took the responsibility of coordinating the study, proofreading of the reported parts, revision, and giving feedback. Four writers in the research team have experience and academic studies about qualitative research. In this sense, the study is teamwork in which four authors took responsibilities on different levels at each stage.

\section{Data Collection Tools}

This study aimed to collect data based on the opinions of the mothers who have children with special needs, a semi-structured interview form was used. To collect the data, first:

Working conditions and legal rights of the healthcare professionals who have children with special needs were examined.

a) Field studies that include regulations made and supports provided for the mothers and their children in the pandemic process were examined; four researchers held online discussion sessions at certain times each week in February-March-April (2020). In these sessions, the legal regulations of the Ministry of Health and Ministry of National Education were examined closely.

b) As a result of the literature review, the study which was planned to be conducted with the healthcare professional mothers about the coronavirus process in our country was decided to be conducted; The concepts of the child with special needs and healthcare professional mothers were focused on during March and April (2020). Care, education, interaction, social supports, family environment, and mother-child experiences were examined. Then, a pool that included interview questions based on the literature was created, these questions were submitted for the opinions of two faculty member experts who have working experience in early childhood, educational assessment, families, and teachers. The opinions of the experts on the questions were taken under the titles "appropriate, not appropriate, should be changed". The final version of the interview form was prepared according to their suggestions about the interview form (reducing the number of questions, emphasizing healthcare professional mother in the questions where working mother concept can be perceived stronger, asking partner-relative support in the education and care of the children in Covid-19 period in a separate question in detail, etc.). The form consists of two sections. The first section includes the demographic information of the child with special needs, the second section includes the personal information of the healthcare professional mothers and interview questions. The interview form includes 10 open-ended questions (Table-2 Semi-structured interview questions form). Ethics Committee Approval is available for the planning and implementation stage of the study. Ethics 
committee approval was approved by Hasan Kalyoncu University Institute of Social Sciences Ethics Committee decision numbered E-804.01-2011250028.

Table 2.

Semi-Structured Interview Questions Form

Experiences of Healthcare Professional Parents Who Have Children with Special Needs in Covid-19 Pandemic Process

Demographic Information Form

Child's age: Child's gender: Child's area of special need:

Parent's age:

Participant's degree of closeness to the child: Age: Gender: Job Status:

Working hours during COVID-19: Who takes care of the child during COVID-19?

Did you stay separate during COVID-19?

Do you receive special education service during COVID-19? If you do, from whom and how?

\section{Interview Questions}

1-What position do you work in in the healthcare industry?

2-Can you tell us about the period you stayed away from home during the COVID-19 pandemic and the period before this process?

3-What can you tell about the differences between your daily routines during COVID-19 and before?

4-How did having a child with special needs affect your life during COVID-19?

5 -What are the legal rights of the parents who have children with SN during COVID-19? Did you continue to benefit from these rights during the pandemic?

6-Can you tell us your experiences if you have stayed away from your home during this period?

7-How were the home climate and your communication with the family members affected during this period? What changes did you experience?

8-How do you try to spend time with your child out of your working hours?

9-Who supported you most in this process? Can you shortly tell us these supports?

10-You have a child with special needs at home and hospitals are the places where the pandemic exists/is experienced most intensely; thus, can you tell us your emotions and precautions?

\section{Data Collection Process}

Participant mothers were interviewed on the telephone due to both the risk of transmission threatening health and lockdowns since the data collection period was in the Coronavirus (Covid-19) pandemic process. Before the interviews, appointments were made for the interview by asking the mothers about the day and hours they were available for. Permissions were also obtained to record the interviews. The researchers first paid attention to that the environment where they would conduct the interviews was appropriate before the interviews were conducted. In this sense, they paid attention to the quietness of the environment and kept the equipment ready to take written notes during the interview. The participant mothers were reminded of the aim of the study and their approval was received for voice-recording. The questions in the interview form were asked to the mothers in the same order. The interviews were conducted in 10 days between 05.05.2020-15.05.2020. The interviews lasted approximately 11-25 minutes (Total duration=127 minutes), mothers and the family members mentioned in the interviews were given code names by taking ethical factors into account.

After the data were collected, the voice records and notes of the interviews were transferred into written transcripts on the computer and saved as a Word document by the instructors. After the interviews were transferred into writing, 74 pages of data were obtained in total. To determine the accuracy of the written transcripts and notes, written transcripts and voice records of three interviews were examined to calculate inter-evaluators reliability; it was seen that there were no differences among the written transcripts/notes and written transcripts of voice records as a result of the examination. Then, the data analysis stage started. Content analysis was conducted to explain the data 
Demiröz, Yıldırım Parlak, Küçük Karahan \& Kayhan - Çukurova Üniversitesi Eğitim Fakültesi Dergisi, 50(2), 2021, 749-777

obtained and to reach concepts. Content analysis is stating themes and sub-themes that allow explaining the concepts and data reached by the data obtained (Yıldırım \& Şimşek, 2018). The repeating statements were determined by reading the data and in this sense, codes were created. After this stage, related codes were combined and themes and sub-themes were created. Five main themes and 27 subthemes were developed as a result of the content analysis. Two researchers conducted interjudge reliability studies regarding the themes created. The agreement was calculated $95 \%$ using Miles and Huberman (1994)'s (Agreement/Disagreement) x 100 formula for the codes determined, themes, and sub-themes (Miles \& Huberman, 1994).

\section{Findings}

This section includes the findings reached by the analysis of the answers that the healthcare professional mothers who have children with special needs gave for the interview questions. The findings include the opinions of the mothers about the home and work experiences during the Covid-19 process and consist of five main themes and 27 sub-themes. The data were made into a table according to the main themes and sub-themes.

I. Main Theme: Working Conditions

Table 3

Work Experiences of Working Mothers

\begin{tabular}{cl}
\hline Main Theme & \multicolumn{1}{c}{ Sub-theme } \\
\hline & 1- Changes in working days and hours \\
& 2- Working with risk group \\
3- Cancellation of the right to leave & 4- Working conditions in accordance with the Health \\
& Services Unit \\
& 5- Cooperation in workplace environment \\
6- Not receiving support
\end{tabular}

Healthcare professional mothers drew attention to the differences in the working conditions during Covid-19 and stated that they have intense working hours. These changes include working days, shifts, and working hours. Participants, also stating that they experienced intense working hours, expressed that they experienced an increase in working with especially elderly patients. For example, Su: 25 cases a day. My working hours are 24 hours 72 days. But it is not clear at all. I have had 17 shifts this month. The ones who wanted shifts would take shifts before, but now 13-14 shifts are compulsory. It's a difficult process; Rüya said: We work the same shifts. I mean, it was called flexible working but we work the same working hours as a university hospital and stated that no regulations were made for the working conditions. Fatma drew attention to the difficulty of working with the individuals in the risk group by saying: a lot of old people come to our unit. We are afraid.

Rüya expressed the difficulty in using the permission and legal rights related to working life by saying: First, when I took time off work, when my child was ill, well, I mean, the administration called me, if it was a real report? I mean, if it is not, tell us... Even they did not believe, I mean, it was how we were, they did not want me to take time off work.

Mothers also stated that they could not spare enough time for their children in the home environment, their level of burnout, anxiety, and stress increased when they went to work. They emphasized that they expect more understanding, social support, and cooperation from their colleagues during the pandemic. For example, Rüya said: I said I shouldn't be working. I mean, I can't work. This is my legal right. But, well, is it written in the law? In which notice? Bring me the law. In fact, I submitted the laws to the head nursery. I said it is written here, that is written there, and expressed the process and difficulties in communication. Contrary to Rüya, Emine emphasized the importance of social support related to legal regulations in workplace environment and said: As the night shifts were started, and I 
Demiröz, Yıldırım Parlak, Küçük Karahan \& Kayhan - Çukurova Üniversitesi Eğitim Fakültesi Dergisi, 50(2), 2021, 749-777

had a little child, they said, you can go, another personnel without a little child can work this shift. I was out of the laboratory but I provided support anyway

\section{Main Theme: Needs Arisen}

Table 4.

Needs of Working Mothers

\begin{tabular}{ll}
\hline \multicolumn{1}{c}{ Main Theme } & \multicolumn{1}{c}{ Sub-theme } \\
\hline & 1. Need for knowing the legal rights and access to \\
legal rights & \\
2. Need for family education & 3. Need for support in child care \\
& 4. Material need for education and supportive \\
& applications \\
\hline
\end{tabular}

In the second main theme, the needs of the working mothers shown that they experienced a difficult process both in terms of their profession and in terms of their children whom they took care of at home. The mothers stated they made concessions to control both two fields, work, and family life. Rüya summarized the difficulty she experienced in the process by saying: I requested, well, we requested to take administrative leave from the hospital. As we have a special child. They answered my request negatively. I mean, they had to, I was working in a better service. I mean more comfortable. They took me to the emergency. I can say I worked more intensely. Hülya: Well, our colleagues, they support me when I am absent, I support them when they are absent, in this way, there are no problems. Only they understand me, and stated that she did not receive enough support except her colleagues in her working conditions. Gamze: In this process, they are with the father now, we take turns. I mean, the father waits, I come, and the father goes to work when I arrive home. As the father's job is in the private sector. There is no other support, and drew attention to support need. Fatma's opinion about child care: I have no one, I am down, and my babysitter takes care of the child. My husband left us after my daughter's diagnosis, I am alone as a mother. What can I do?, and drew attention to the difficulties she experienced. Fatma, stating that she is the only parent due to she is separated from her husband, stated that this situation was not taken into account during Covid-19 and said: Permissions are rejected, we don't know our legal rights. I only know the shifts. I don't know our rights except for it. We cannot reach. I need to work for the education of the children. Education is too expensive. I think about not working, there is no one to take care of the children but I have to. I work for my child not to fall behind, and emphasized the economic and social troubles she experienced.

\section{Main Theme: Changing Lifestyles with Covid-19}

Table 5.

Effects of Covid-19

\begin{tabular}{cl}
\hline Main Theme & \multicolumn{1}{c}{ Sub-theme } \\
\hline & 1- Psychological processes \\
2- Changes in daily routines \\
3- Increase in the technology use \\
Changing Lifestyles with Covid-19 & 5- Importance of security skills \\
& 6- Anxiety about the virus \\
7- Changes in eating habits \\
\hline
\end{tabular}

In the third theme of the study, mothers drew attention to the changing routines and habits in their lives with Covid-19. They stated that they had anxiety due to taking all responsibilities at home and work with the increase in the time spent at home. Mothers, drawing attention that they experienced anxiety about the care and security of their children, stated that the resources that cause this anxiety are security skills, fear of transmitting the virus to the family members. They also emphasized that they 
Demiröz, Yıldııım Parlak, Küçük Karahan \& Kayhan - Çukurova Üniversitesi Eğitim Fakültesi Dergisi, 50(2), 2021, 749-777

experienced a feeling of loneliness due to not being able to visit relatives, they experienced physical activity restriction in the period they stayed home, and eating disorders increased.

Emine said: When I started to work in the laboratory, her grandmother had to live with us. Because we had to have a disinfection process as I was not able to take the child into my arms. I had to wash my hands and face and get cleaned even for holding the child, and mentioned the changes in the family life and the fear of transmitting the virus to the child.

Fatma stated that her child with special needs felt uneasy in social life with her security skills and stated that: I was taking her out a little, very little. Because she is not completely aware of what is going on, I mean, she also wants to let go of our hands and run, she falls, stands up or she wants to get away from us, she does not exactly know.

Su said: She does not go to bed until 1, 2. Of course, this process affected both the children and us. I can say that we psychologically got exhausted with the fear of transmission to the child, and expressed her fears about the process. Fatma, one of the mothers who drew attention to their emotional exhaustion, said: I developed depression, my heart rate increased. I had a lot of difficulties. I got exhausted with the fear of transmitting the virus. I was affected a little. From home to work, from work to home, I don't have a social life. Everything depends on you, and drew attention to the effects of the process on her.

IV. Main Theme: Mothers' Experiences with Online Education

Table 6.

Mothers' Experiences with Online Education

\begin{tabular}{cl}
\hline Main Theme & \multicolumn{1}{c}{ Sub-theme } \\
\hline & 1- Lack of support from institutions \\
& 2- Lack of instructional adaptations \\
Experiences with Online Education & 3- Lack of support from general education teachers \\
& 4- Increasing the awareness of the families \\
& 5- Lack of online education \\
\hline
\end{tabular}

Another difficulty experienced by the mothers who participated in the study is not being able to meet the educational needs of their children in the Coronavirus (Covid-19) process. The difficulties stated by the mothers are, respectively, that their children with special needs fall behind in education, they cannot go further from where they came before the pandemic, the institutions do not show the necessary support in this process, and their information needs about the online education are not met. Fatma stated that they need support about how to teach the skills and behaviors to her child in this process and said: We receive support from the institution once a week, but it is not enough. I don't know how to do. He shows problem behavior. I don't know how to support him. Emine: We have lots of needs about the education, the school provided lots of benefits in the cognitive sense. I support that the schools should be opened after the necessary precautions are taken. Because my son cannot do all homework, and emphasized that educational adaptations should be made for the children with special needs and they should be supported in accordance with their development. Gamze stated that: Inclusion continues, I mean, from this or that book, well, I mean, you will solve the exercise on that page in maths book and send me a video. That poem will be read, you will send me a video while reading, and they send these kinds of messages. How are we going to do?, and stated that the educational adaptations are insufficient. Su said: they send education videos and say do it in this way. We do, it's wrong, they did not teach us how to do it. Special education cannot be provided with distance online education, it's too difficult, and stated that they could not receive the desired efficiency, guidance, and feedback in online education. 


\section{Main Theme: Opinions and Suggestions}

Table 7.

Mothers' Opinions and Suggestions

\begin{tabular}{cl}
\hline Main Theme & \multicolumn{1}{c}{ Sub-theme } \\
\hline & 1-Failure of education in providing education services \\
& 2-Increasing the teacher competencies \\
Opinions and Suggestions & 3-Increasing the quality of special education \\
& 4-Demand for face-to-face education \\
5-Extending the legal rights granted to working \\
parents
\end{tabular}

Mothers' suggestions are generally related to meeting the needs of their children. When examining the opinions, the anxiety about the education and care of the children is prominent. On this subject, Fatma: If everyone is aware, I mean, institutions have commercial purposes. I mean, teachers are more qualified, if they supported us more, if they were more qualified, had more knowledge in language and speech, I mean, if they guided us, and express that the quality of the institution, education, and teacher should be increased. Important points highlighted by mothers are: decreasing the workload, providing support from home, amendment of legal rights, continuing the care and education of the children without difficulties. When examining the suggestions regarding this, legal regulations should be made and differences in implementation should be stopped.

As a result of this study that focuses on the experiences of healthcare professional mothers who have children with special needs, it draws attention that the role and responsibilities of the mothers in the family have increased, they experience anxiety about these responsibilities they take intensely. It is concluded that the mothers usually had to deal with the problems on their own, they need support for carrying out their responsibilities both in work life and at home.

\section{Discussion \& Conclusion}

This study has examined the opinions of the healthcare professional mothers who have children with special needs about their work, family life experiences in the Coronavirus (Covid-19) process. In the Working Conditions Theme (Theme 1), mothers drew attention to the changing working life with the Covid-19 pandemic. Mothers drew attention to the changes in their working hours and duration of working with risk groups, emphasized the cancellation of the right to leave and changes in the working conditions according to the healthcare services units. They stated that they expected to take characteristics of the children and family environment to be taken into account in the regulations for working conditions, and they had to deal with problems such as limited cooperation and lack of support in the work environment. The issue the mothers are most anxious about is transmitting the virus to their families, being late in taking precautions, or not being able to take enough precautions. The literature includes similar finding (Baki \& Piyal, 2020; UNICEF, 2020a). UNICEF states that adults get more anxious about their children with special needs as they think their immune system is low in the Covid-19 period. As stated in the report published by UNICEF (2020a), Covid-19 has put children with special needs at higher risk of catching an infection and becoming seriously ill due to some underlying health problems. In the study by Baki \& Piyal (2020), it was stated that the healthcare professionals were affected by this process a lot and had the fear of transmitting the virus to the individuals with whom they live at home. This finding also shows similarities with the literature findings regarding the mothers' increasing working conditions with the pandemic, increase in the work-home burden, and in-family conflicts. While mothers stated that they received support from their colleagues in the work environment, very few stated that they did not receive support and this was challenging for them. Another research finding that coincides with this result is the research by UNICEF (2020b), which draws attention to the support for healthcare professional parents in the Coronavirus pandemic. As a result of the research, UNICEF (2020b) published a report that consisted of seven suggestions for employers. The report especially drew attention that the women have more responsibilities than the men (balance role in working life, home life), thus, it is emphasized that the mothers should be protected from punitive treatment in the situations such as 
Demiröz, Yıldırım Parlak, Küçük Karahan \& Kayhan - Çukurova Üniversitesi Eğitim Fakültesi Dergisi, 50(2), 2021, 749-777

taking leave or distribution of shifts due to their decisions. It is stated that precautions should be taken to protect working mothers. Because it is stated that while a great majority of mothers were protected in their workplace during the pandemic period (not being fired, not being exposed to discriminatory behavior, etc.), some mothers were exposed to punitive treatment.

In Theme 2, it is indicated that some needs became prominent for the mothers and their children in the pandemic environment. Needs such as being with their children with special needs at home for their education and care, and continuing their working life due to financial reasons at the same time shown intensity for the mothers. It was concluded that they were left alone with the problems that make their workload heavier when the employers or managers to whom they are responsible in business life do not take the needs of the mothers who have children with special needs into account. Mothers defined these problems as obtaining information about their legal rights, using their legal rights, informing the authorities, attainability, and accessibility of the laws, positive effect of female managers, and request for administrative leave. A study that supports this finding belongs to Yıldırım \& Hacıfazlıoğlu (2019). Yıldırım \& Hacıfazlıoğlu (2019) stated that the reason why the working mothers continue their business life is financial difficulties and the mothers cannot use their legal rights in business life and have problems with their managers. This result shows similarity with the findings of this study. In another study conducted with healthcare professionals who have children with typical development, it was stated that the managers did not let the personnel use their right to leave even though they had the legal right and the personnel could experience some pressure from the managers (Nakışçi, Kavas \& Develi, 2020). Accordingly, it can be concluded that the process is more complicated for working mothers and their children with special needs. Healthcare professional mothers who participated in this study also emphasized that they frequently took care of their children's education since the institutions were closed related to the continuation of the pandemic. The need for family education to support their children at home arose in this process. The studies conducted revealed that the mothers mostly need family education appropriate for their children's needs (Toy \& Kesici, 2020). The families cannot receive support and have difficulty in dealing with the problems that arose since the institutions are closed during the pandemic process (Akoğlu \& Karaaslan, 2020). In a study conducted to determine the needs of teachers in the Covid-19 process, Karahan, Demiröz, Yıldırım, and Özaydın (2020) similarly stated that the families and teachers need an increase in the family education and they need to receive feedback. Another study conducted to determine the needs of the families in the Covid-19 process belongs to Yıldırım, Karahan, Demiröz, Şener, and Özaydın (2020). Working mothers stated that their need for care support for their children has increased and they have been going through a difficult period; they indicated that they need child care support and daily care services. The finding that states that the healthcare professional mothers experience stress and think of leaving their profession due to the working conditions such as not being able to use their legal rights shows similarity with the finding of the study conducted by İmirlioğlu (2009).

In theme 3, the mothers defined their changing lifestyles in the Covid-19 process as psychological processes, routines regarding home life and children, including technology in our lives, the importance of security skills, anxiety about the virus, restriction of social life, changes in the eating habits. It draws attention that the mothers experienced a feeling of loneliness and psychological burnout in meeting the needs of their children with special needs with the increase in the workload. Changing routines, decrease in the time spent at home with their children, cancellation of their right to leave led to psychological pressure on mothers. The increase in the time spent at home and not being able to go to public areas due to the social isolation because of the pandemic made the process harder for the mothers. They also stated that the mobility in daily life decreased and the eating habits at home changed as a result. In a similar study conducted with mothers, it was stated that the mothers experienced burnout, needed dietitian help, and their social life was restricted in the Covid-19 process (Yıldırım et.al, 2020). In the study conducted by Nakışçi, Kavas \& Develi (2020) on the female healthcare professionals, mothers stated that the burden of child care and housework is on them and they had difficulty in balancing the work and life. In a similar study, Ameias, Lai, Mulsant \& Szatmari (2020) stated that the changing routines in the Covid-19 process caused mothers to make regulations at home, take 
precautions about the security cautions, and consequently, the mothers' need for support for new routines increased.

In theme 4 , the mothers emphasized that they could not receive sufficient support from the institutions and teachers for the education of their children in this process and could not benefit from the online education at the level they expected. In the literature, it has been emphasized that the disadvantageous groups are affected more in the Covid-19 process, cannot benefit from education sufficiently and the families take new roles and responsibilities that support learning (Report of United Nations, Bozkurt, 2020). Göl-Güven et.al. (2020) emphasized that mothers can develop anxiety regarding the education of their children when they cannot receive feedback on the practices expected from them at home in online education provided without taking the individual differences of the children into account. It is especially stated that distance education is not beneficial for the children with special needs and does not meet the needs. In the literature, it was stated that the access to the distance services should be increased to reduce or prevent the negative effects of Covid-19 and similar processes such as pandemics in the future; technological devices should be provided to the families (Amaral \& Vries, 2020; Ameias, Lai, Mulsant \& Szatmari, 2020). These findings show similarity with the points emphasized by the mothers in this study.

Covid-19 pandemic has made life difficult for everyone, especially for the children whose routines are disrupted, who experience changes and stay away from education, and for the families. Staying away from educational processes for a long time increased the anxiety of the families who have children with special needs about education. As indicated by the mothers in the interviews, mothers stated that they could not be included in the education of their children and their knowledge was insufficient when the online education was insufficient. Not being able to provide the support they wanted to give to their children in the education field increased their anxiety about their children's education. It can be concluded that the families need education and support based on all these findings. Many organizations emphasized that the families should spend this process without anxiety, thus, they tried to provide support for their well-being. For example, websites that teach how to use masks and hygiene rules for the children with special needs were designed; family education and information were given; online support was provided to make them spend the process better (European Communities Trade Mark Association [ECTA], 2020; The University of North Carolina at Chapel Hill [UNC], 2020).

In conclusion, supportive education that is provided evaluating the needs of the children within the family integrity makes the process easier for the children and their families. In this sense, it is important for families who have children with special needs to reach supportive education. It is thought that the teachers who have a great role in the process and other special education stakeholders must have qualified professional skills and cooperation competencies (Mereoiu, Abercrombie \& Murray, 2016; Olçay-Gül, 2014). The studies show that the supports are not at the level expected since the general education teachers do not know how to make educational regulations while giving education to children (Aydın \& Tuğluk, 2020; Sönmez, Alptekin \& Bıçak, 2018). It is an important subject that the teachers need support about what they can do with the children with special needs. In another study, (Karahan, 2019) stated that the parents experience some limitations in taking care of their children and sharing information when the general education teachers do not have professional competencies. This finding shows similarity with the study finding.

Lastly, the opinions and suggestions of the mothers who participated in this study indicate that regulations are needed for their children. The mutual opinion is that the mothers do not want their children to fall behind in special education and want face-to-face education. It is also seen that their anxiety level for the process and the future is high. The reason for the problems experienced by the mothers, who develop stress and anxiety because of the health risk on one hand and the increase in the responsibilities of their children on the other hand in work in Covid-19 process is due to the fact that the type, level and care responsibilities of the children are not taken into account. Because the mothers emphasized that the education and care institutions were closed in this process and they could not receive care support from the close relatives, grandmother, and grandfather due to the pandemic risk. 
However, sufficient communication with the family and environment, establishing relationships, and receiving support from them are among the factors that protect against stress (Ministry of National Education, 2020). Mothers stated that they cannot reach these factors sufficiently as mentioned above, thus, they emphasized that their legal rights should be improved in the regulations regarding the new normal; regulations that will provide their participation in the work environments without neglecting their children's care, education and health and that will protect their well-being in their own work-life and parenting roles should be made.

Suggestions to the authorities of the institutions based on the results of this study: Managers at work, teachers, and principals at school can plan processes that will provide the participation of the parents in education. Handbooks (printed and digital) can be prepared and shared with the parents to support children and to continue education in terms of preparation for the Covid-19 pandemic and similar situations such as natural disasters and pandemics. Regulations based on family participation can be planned. Corporate policies can be followed for working mothers to cooperate with the teacher about the education of the child through a mobile application. In this regard, cooperation can be published with the Ministry of National Education and a process based on the active use of EBA and other information platforms by families can be followed. By supporting the mobile applications with educational content, families can follow a positive process in terms of supporting their children at home in a planned manner while continuing their business life. To provide feedback to the families, sharing and activities with expert-teacher-parent participation can be organized face-to-face or online by taking the current conditions into account. Qualitative researches including large samples can be planned on a larger scale, focus group interviews can be conducted where the opinions of teachers, parents, and students are taken and they can make reflections based on their experiences. Practices that include planning of health services and personnel satisfaction and needs in the Covid-19 period can be planned with the participation of health institution managers. Opinions and experiences of the education institution managers regarding distance education in the Covid-19 process can be examined in the scope of cooperation with families.

During the implementation, data collection, analysis, and transferring the data into findings processes of this study, the data of which were collected with semi-structured interview technique in qualitative research method, all the rules in Higher Education Institutions Scientific Research and Publication Ethics Directive were obeyed, and none of the "Actions Contrary to Scientific Research and Publication Ethics" in the second part of the directive was carried out. 


\section{Türkçe Sürümü}

\section{Giriş}

Yaşamın ilk yıllarını kapsayan erken çocukluk dönemi, çocukların gelişimlerinin oldukça hızı olduğu kritik bir dönemdir. Bu dönemde çocukların bilişsel, dil, akademik ve sosyal açıdan gelişimlerinin temeli atılmaktadır. Çocukların aile içi ve sosyal çevre ile iletişimleri, deneyimleri önem taşımaktadır. Erken çocukluk döneminde çocuklar, sıklıkla onların bakımından sorumlu birinci kişiler olan ebeveynleriyle vakit geçirmektedir. Dolayısıyla doğumla birlikte başlayan bu yıllarda çocuklar gelecekte kullanacakları bilgi, beceri ve deneyimleri en çok ebeveynleriyle gerçekleştirdiği yaşantılar yoluyla kazanmaktadır (McDuffie ve Yoder, 2010). Ebeveynlerin özellikle annelerin, çocuklarıyla gerçekleştirdikleri etkileşim; çocuğun gelişiminde önemli bir yere sahiptir (Mahoney ve MacDonald, 2004). Sonuç olarak gelişimin hızlı oluşu ve çocukların öğrenmeye açık olması sebebiyle bu dönemde, aileye oldukça önemli sorumluluklar düşmektedir (Birkan, 2001).

Birey için gelişimin hızlı olduğu ilk yıllar oldukça önemli görülmekte, çocukların özellikleri bu yıllarda sağlanan bakım ve eğitim hizmetleri açısından önem taşımaktadır. Özel gereksinimli çocukların dil, bilişsel, fiziksel, sosyal, akademik, öz bakım gibi gelişim alanlarında çeşitli gereksinimleri bulunmaktadır. Buna göre erken çocukluk dönemi özel gereksinimli çocuklar için daha da kritik bir önem taşımaktadır. Göstermiş oldukları davranışlarda, bazı düzenlemelere ihtiyaçları olup; çeşitli nedenlere bağlı olarak öğrenme ve iletişim sürecinde, normal gelişim gösteren akranlarından farklı birtakım düzenlemelere gereksinim duymaktadırlar. Örneğin, Otizm Spektrum Bozukluğu olan çocukların beceri ve davranış kazanımlarının desteklenmesi amacıyla tipik gelişen akranlarına göre daha sistematik öğretime gereksinimleri olmaktadır (Orum-Çattık, Yetkin ve Diken, 2019). Olumlu davranış kazanımı açısından da, problem davranışlarının giderilmesine yönelik müdahalelerin önemi ortaya çıkmaktadır. Bu noktada aileler çocuklarının eğitim gereksinimlerini karşılamak için özel eğitim hizmetlerine başvurmaktadır. Erken çocukluk dönemini temel alan erken müdahale çalışmaları, küçük yaştaki çocukların ve ailelerinin sağlık, sosyal ve eğitim alanlarında bulunan gereksinimlerine yönelen hizmetler bütünüdür (Howard, Williams ve Leper, 2010). Bu dönemdeki müdahaleler farklı alanlarda yetersizliğe sahip küçük çocukların, ilerleyen yıllarda bağımsız yaşam becerileri açısından önem taşıdığı gibi; ebeveynlere de bir takım sorumluluklar yüklemektedir (Kanık, 1993). Normal gelişim gösteren küçük bir çocuğa anne babası, günlük yaşantı içinde birçok bilgi ve beceriyi doğal yollarla kazandırabilmektedir. Oysa özel gereksinimli çocuğa sahip olan anne ve babalar için bu bilgi ve becerileri kazandırmak daha güçtür (Orum-Çattık, Yetkin ve Diken, 2019). Bu durumda çocuklarının gelişimini desteklemek amaçlı, aile ve çocuğun bütün olarak desteklenmesi öne çıkmaktadır. Erken çocukluk döneminden itibaren özel gereksinimli çocuklarının eğitimi ve gelişimini nasıl destekleyecekleri noktasında ebeveynlerin desteklenmesi de gerekli görülmektedir (Akt., Munson ve Odom, 1996). Dolayısıyla özel gereksinimli küçük çocukların gelişimleri için anne-babalar ve aile üyeleri ile nitelikli ve sürekli devam eden iş birliğine dayalı çalışmalara ihtiyaç vardır. Bu sebeple özel gereksinimli çocukların ve ebeveynlerinin etkileşimlerinin niteliğinin ortaya konulması, desteklenmesi ve olumlu iletişimlerinin artırılması önemli görülmektedir.

Çocuklarının gelişimlerini desteklemede oldukça fazla rol üstlenen ebeveynlerin, süreçteki motivasyonlarını etkileyen faktörler bulunmaktadır. Çalışma koşulları, hizmet aldıkları kurum ve eğitimden sorumlu öğretmenlerle iş birliği düzeyleri bu değişkenler arasında yer almaktadır. Bu değişkenlerin niteliği aile içi örüntüleri etkilerken, anne-baba-çocuk ilişkisi ve ebeveyn tutumları da sürecin belirleyicileri olarak karşımıza çıkmaktadır (Demirbilek, 2013; Özbey, 2010; Toker, Başgül ve Özaydın, 2019). Bütün bu faktörler çocuğun tanı yaşı, aldığı eğitim hizmetlerinin niteliği, aile katılımı ve zaman planlaması ile ilişkilidir. Nitekim anne ve babalar, özel gereksinimli çocuklarıyla ilgili sorumluluklarının yanı sıra, ev ve iş yaşamına ait sorumlulukları da üstlenmektedir. Özellikle çalışan anne ve babalar özel gereksinimli çocuklarını hayata daha iyi hazırlamak, onların gereksinimlerini karşılamak için zorlu bir süreçten geçerken; aynı zamanda iş yaşamlarının getirdiği güçlükler ile de mücadele 
etmektedir (Karadağ, 2014). Özel gereksinimli çocuğa sahip anne ve babaların yaşadığı bu güçlüklere ilişkin bazı çalışmalar incelendiğinde; annelerin çalışma hayatından etkilendiği, çocuk bakımı ve iş hayatı arasında kalarak ödün verdiği, yöneticileri ve iş arkadaşları ile çalışma saatlerini planlamada zorluk yaşadıkları, yasal haklarını kullanamadıkları ya da bilmedikleri, normal gelişim gösteren çocukların ebeveynlerine göre daha zorlu bir iş yaşamı ile karşı karşıya kaldıkları belirtilmiştir (Hodgetts, McConnell ve Zwaigenbaum, 2014; Yassıbaş, 2015; Yıldırım ve Hacıfazlıoğlu, 2019). Alanyazındaki bu sonuçlar, çalışan anne ve babaların iş yaşamları dışında kalan sürede çocuklarıyla ilgilenmenin güç yanlarını ortaya koymakta; onların birtakım intiyaçları olduğu gerçeğini de belirginleştirmektedir. Bu ihtiyaçlar ebeveynlerin çalıştıkları iş alanlarına göre farklıı göstermekte; dolayısıyla anne babaların iş yaşamına bağlı yaşadığı zorluklar nedeniyle, özel gereksinimli çocuklarına ayırdıkları zaman farklıık göstermektedir. Ebeveynlerin, içinde bulundukları çalışma koşullarının mesleğe özgü irdelenerek, özel gereksinimi olan çocuklarına ayırdıkları zamanın, onların eğitimi ve sosyal gelişiminde üstlendikleri rollerin incelenmesi önem arz etmektedir. Tüm dünyada etkisini hissettiren; eğitim, sağılık, sosyal yaşam, ekonomi, turizm gibi alanları da etkileyen Covid-19 salgını ülkemizde Mart 2020 tarihi itibariyle ortaya çıkmıştır. Salgın sürecinde başka ülkelerde olduğu gibi ülkemizde de sağlık çalışanlarııın iş yüklerindeki artış dikkat çekmiş; sağlık personelinin kendileri ile ailelerini ilgilendiren birtakım desteklere gereksinimleri ortaya çıkmıştır (İzci, 2020). Koronavirüs salgını sağlık çalışanlarının özellikle iş ve günlük yaşantılarını olumsuz etkilemiş; çalışma saatleri ve birimlerinin değişmesine yol açmıştır. Sağlık personelinin çalışma birim ve saatlerinin değişimi sonucu ev rutinleri yoğun olarak etkilenmiş; artan iş yükleri nedeniyle aileleri ve çocuklarıyla bir arada olma sıklıkları azalmıştır. Özellikle sağlık çalışanlarının büyük çoğunluğunu oluşturan kadın personellerin bu dönemde, hastaların sağlıkları ve hayatlarına yönelik hizmet verirken kendi ev yaşamlarını dengelemek adına farklı destek kaynaklarına ihtiyaç duydukları dikkati çekmiştir. Annelerin bu süreçte çalışma şartlarındaki değişikliklerin yanı sıra, evde bekleyen sorumlulukları da artmış, bu durum yüklerini biraz daha ağıllaştırmıştır (Seven, 2020; United Nations International Children's Emergency Fund [UNICEF], 2020c; Zeybekoğlu-Akbaş ve Dursun, 2020). Koronavirüs (Covid-19) ile birlikte sorumluluğu artan sağılık çalışanı anneler ve çocukları için süreç, daha yorucu hale gelmiştir. Annelerin evdeki işleri ve çocukları ile ilgili sorumluluklarına bir de Covid-19'a bağlı değişen yaşam koşulları ile artan iş yükü eklenmiştir. Normal süreçte dahi sağlık çalışanlarının iş yükü, ev ve aile yaşamındaki ilişkileri çoğu zaman zorlayıcı bir süreç özelliği taşırken; salgın sürecinde artan iş yükleri birtakım zorlukları da beraberinde getirmiştir (Baki ve Piyal, 2020). Salgın döneminde riskli çalışma koşullarına bağlı olarak sağlık çalışanları ve aileleri üzerinde, panik ve kaygı durumları daha yoğun gözlenmiştir (Amakiri ve diğerleri, 2020). Psikolojik olarak tipik gelişim gösteren çocuklara sahip çalışan anneler de iş ve aile çatışması durumları ile karşı karşıyadır. Ancak annelerin iş yaşamı dışında, özel gereksinimli çocuklarının eğitim ve destek gereksinimlerinin farkıış̧masına bağlı sorumlulukları artmış, sağlık açısından riskli bir salgın sürecinde çalışma hayatında yer almışlar aynı zamanda ev ve çocukların sorumluluğu ile Covid-19 dönemini daha farklı bir tablo ile karşı karşıya kalarak deneyimlemişlerdir. Bu anlamda sağık çalışanı annelerin deneyimlerinin doğrudan kendi bakış açıları ve algılarına dayalı incelendiği, salgın sürecini nasıl geçirdiklerinin çalışma koşullarına bağlı irdelendiği araştırmaların önemli olduğu düşünülmektedir. Alanyazında çalışan annelerin normal süreçte dahi, iş ve yaşam dengesini kurmakta zorluk çektiği yer alırken (Yıldırım ve Hacıfazlıoğlu, 2019); salgın süresince gerçekleşen sosyal değişimler iş yaşamına bağlı uygulamalar; bir yandan annelerin ev yaşamındaki dengeyi kurmada güçlükler yaşamalarına neden olmuş, onları bazı zorluklarla karşı karşıya bırakmıştır. Nitekim çalışan annelerin ev ve iş yaşamındaki rutinleri dışında gerçekleştirmekle sorumlu oldukları, çocuklarının sağlık, eğitim süreçlerindeki sorumlulukları da eşleri ve aile üyeleri ile paylaşma rolleri bulunmaktadır. Çalışan annelerin salgın sürecinde bu sorumlulukları; fiziksel temasın azalması, kısıtlamaların devam etmesi, bir başka yardımcıdan ev içi yaşama ilişkin destek alamamaları nedeniyle artmıştır. Tüm bunların sonucunda sağlık çalışanlarının sosyal, ev ve aile yaşantıları kısıtlanmış; kendileri ve aileleri için ayırdıkları zaman azalmıştır (Zeybekoğlu-Akbaş ve Dursun, 2020).

Koronavirüs (Covid-19) sürecinde sağlık çalışanları, mesleki görevlerinden dolayı daha fazla risk altında kalmış, bu durum başlı başına bir kaygı nedeni olmuştur (Çetintepe ve Illhan, 2020). Mesleklerine bağlı risk altında olmaları aile içi bütünlüğün sağlanması adına sorumlulukları, çocukları, eşleri ve yakın çevreleri ile bir arada geçirilen zamanın sınırlı olmasına yol açmış, sonuç olarak sağlık çalışanlarına iş 
Demiröz, Yıldırım Parlak, Küçük Karahan \& Kayhan - Çukurova Üniversitesi Eğitim Fakültesi Dergisi, 50(2), 2021, 749-777

yüklerinin yanında birtakım duygusal yükler de eklenmiştir. Bu duygusal yükler sonucunda sağlık personelleri kendilerini daha fazla çaresiz hissetmiş, daha yoğun kaygıyla baş etmek durumunda kalmışlardır (Huremović, 2019). Tüm bu faktörler birleştiğinde anneler; aile içi yaşamdaki sorumlulukları ve çocuklarının gerek sağlık gerekse eğitim, bakım, sosyal uyum gibi süreçlerinde üstlendiği roller bakımından daha yoğun bir kaygıya maruz kalmışlardır. Ayrıca salgın döneminde okullar ve kreşler kapatılmış, bu uygulama çalışan anneler için süreci daha karmaşık hale getirmiştir. Anneler bir yandan iş ve sosyal yaşamdaki risklerden dolayı kaygıları ile baş etmek durumunda kalırken; diğer yandan ev içi sorumlulukları, çocuklarının sağlığı ve eğitimleri adına rollerini gerçekleştirmeye çabalamışlardır (UNICEF, 2020a). Bu yaşantılar salgın sürecinde sağlık çalışanlarından özel gereksinimli çocuğa sahip olan ebeveynleri de olumsuz etkilemiştir. Salgın öncesi dönemde özel gereksinimli çocuğa sahip çalışan anne ve babalar evde geçirdikleri zamanlarını çocuklarının ihtiyaçlarına ayırmakta ve onları gereksinim alanlarına göre desteklemekte iken; salgın sürecinde kreş, anaokulu ve özel eğitim desteği aldıkları merkezlerin önlem amaçlı kapalı olması, bakım desteği veren kişilerin tedbir amaçlı evde destek sürecine devam edememesi aileleri ve özel gereksinimli çocuklarını olumsuz etkilemiştir. Çocuklarının ihtiyaçlarını ve bakımını yerine getirebilmek için başkaları tarafından desteklenmeye ihtiyaç duyan sağı alanında çalışan anne ve babaların, bu süreçten en az tükenmişlik düzeyiyle ayrılabilmesi ve çocuklarının eğitim, bakım ihtiyaçlarının karşılanabilmesi adına yeni dönemde düzenlemeler yapılması gerekmektedir (UNICEF, 2020a).

Sonuç olarak, Koronavirüs sürecinde ailelerin neler yaşadıklarının bilinmesi, yeni normal dönemde ne tür gereksinimlerinin olabileceği ile ilişkilidir. Özellikle çalışan annelerin gerek Koronavirüs döneminde gerekse normale dönüş sürecindeki çalışmalarda ne tür desteğe ihtiyaç duyduklarının belirlenmesinin önemli olduğu düşünülmektedir. Gerçekleşecek düzenlemelerde bu ihtiyaçların dikkate alınması gerekmektedir. Dolayısıyla özel gereksinimli çocuğu olan sağlık çalışanı annelerin çalışma koşullarına dikkat çekmek ve salgın sürecinde yaşamlarını kolaylaştırmak adına iş ve aile ortamına ilişkin deneyimlerini inceleme gereksinimi doğmuştur. Bu gereksinimden yola çıkarak planlanan araştırmanın amacı, özel gereksinimli çocuğa sahip olan sağlık çalışanı annelerin Koronavirüs (Covid-19) sürecindeki deneyimlerinin incelenmesidir. Çalışmada aşağıdaki sorulara cevap aranmıştır:

1- Sağlık çalışanı annelerin Koronavirüs (Covid-19) sürecinin özel gereksinimli çocukları, kendileri ve aile üyelerinin yaşamındaki etkilerine ilişkin görüşleri nelerdir?

2- Sağlık çalışanı annelerin Koronavirüs (Covid-19) sürecindeki deneyimleri sonucu yeni normal süreçte iş, ev ve sosyal yaşama ilişkin düzenlemeler hakkındaki görüş ve önerileri nelerdir?

\section{Yöntem}

Araştırmanın desenine, katılımcılarına ilişkin bilgiler ile araştırmacılar, demografik bilgiler, veri toplama aracı, verilerin toplanması ve analizine yönelik bilgiler bu bölümde ele alınmıştır.

\section{Araştırma Modeli}

Bu araştırma, Covid-19 salgın süresince sağlık çalışanlarından özel gereksinimli çocukları olan ebeveynlerin deneyimlerini belirlemek üzere nitel araştırma yöntemlerinden Olgubilim (Fenomenoloji) ile desenlenmiştir. Olgubilim, bireylerin deneyimlerinin özünü tanımlayan, yaşam deneyimlerinin derinlemesine betimlendiği desendir. Derinlemesine betimleme yaparken 'neyi' ve 'nasıl' deneyimlediklerine odaklanılır (Creswell, 2016). Araştırmada katılımcı annelere sorulan sorularda derinlemesine bilgi toplamada esneklik sağlanması açısından yarı yapılandırılmış görüşme tekniği kullanılmış; bu amaçla özel gereksinimli çocuğu olan sağlık çalışanı annelerin deneyimlerine yönelik görüşmeler gerçekleştirilmiştir.

\section{Çalışma Grubu}

Araştırmanın katılımcıları, Güneydoğu Anadolu Bölgesi'nde bir il merkezinde bulunan Büyükşehir Belediyesi Engelsiz Yaşam Merkezi ve özel eğitim rehabilitasyon merkezlerine devam eden çocuğa sahip sağlık çalışanı altı anneden oluşmaktadır. Öncelikle merkez ve kurum müdürleriyle telefonla ve çevrim içi ortamda görüşmeler yapılmıştır. Görüşmelerde araştırmanın amacı açıklanarak, gerekli izinler alınmıştır. 
Ardından kurum müdürleri aracılığıyla annelere ulaşılarak, telefon görüşmeleri yapılmıştır. Bu görüşmelerde amaca ve etik kurallara (araştırmaya katılan grubun ele alınması, verilecek bilgilere yönelik gizliliğin esas olması, elde edilen verilerin bu çalışma dışında farklı bir amaç için kullanılmayacağı, onam formları ve görüşmelerin katıımcı onayları doğrultusunda ses kaydı alınacağı gibi) yönelik açıklamalar yapılmışır. Ayrıca araştırma sürecinde yönlendirilen soruların doğru veya yanlış bir cevaba sahip olmadığı belirtilmiş; çalışmaya gönüllü katılımlarına yönelik onayları alınmıştır. Araştırmanın herhangi bir aşamasında istedikleri takdirde araştırmadan çekilme hakları olduğu vurgulanmıştır. Anneler ve özel gereksinimli çocuklara ait demografik bilgiler Tablo 1'de yer almaktadır.

Tablo 1.

Özel Gereksinimli Çocuklar ve Annelerine Ait Demografik Bilgiler

\begin{tabular}{|c|c|c|c|c|c|c|c|c|c|}
\hline & & Ann & erin Özellikleri & & & Ö. G & Çocukla & rın Öze & ellikleri \\
\hline Kişi & Kod Ad & Yaş & Meslek & Eğitim & Çalış.Saat & Yaş & Cins. & Tanı & $\begin{array}{l}\text { Çocuk } \\
\text { Bakım }\end{array}$ \\
\hline Anne1 & Fatma & 38 & Hemşire (İdari) & Lisans & Esnek & 4 & Erkek & D.S. & $\begin{array}{l}\text { Baba } \\
\text { Desteği }\end{array}$ \\
\hline Anne2 & Su & 35 & Hemşire (112) & Yük. Lis & Yoğun & 5,5 & $\mathrm{~K} \mathrm{Iz}$ & OSB & Bakıcı \\
\hline Anne3 & Rüya & 35 & Hemşire (Acil) & Lisans & Esnek & 8 & Erkek & OSB & Baba desteğ \\
\hline Anne4 & Emine & 30 & Biyolog & Lisans & Esnek & 2 & Kız & DS & Aile Büyüğü \\
\hline Anne5 & Hülya & 38 & Hemşire & Lisans & Esnek & 7,5 & Kız & $Z Y$ & Yard.Öğr. \\
\hline Anne6 & Gamze & 37 & Satın Alma M. & Lisans & Esnek & 7 & Erkek & OSB & $\begin{array}{l}\text { Baba } \\
\text { Desteği }\end{array}$ \\
\hline
\end{tabular}

Tablo 1'de belirtildiği gibi katılımcı grubunu oluşturan altı anne 30 (Emine) ve 38 yaş (Fatma ve Hülya) aralığında olup; annelerin 4'ü hemşire (Fatma, Su, Rüya, Hülya) olarak görev yapmaktadır. Annelerden biri yüksek lisans (Su) diğerleri lisans düzeyinde eğitime sahiptir. Çalışma saatleri incelendiğinde 112-Acil Servis Hemşiresi olarak görev yapan Su hariç diğerleri, esnek çalışma modelinde mesaiye devam etmekte; çocuklarının bakımın ise aile büyüğü (Emine) ve babaların desteğiyle dönüşümlü çalışma uygulaması kapsamında sağlamaktadırlar (Fatma, Rüya ve Gamze). Annelerin özel gereksinimli çocukları iki ve sekiz yaş aralığında olup; Su, Rüya ve Gamze'nin çocuklarının Otizm Spektrum Bozukluğu (OSB) tanısı bulunmakta; Fatma ve Emine'nin çocuklarının Down Sendromu, Hülya'nın kızının ise Zihin Yetersizliği (ZY) tanısı olduğu görülmektedir.

\section{Araştırmacilar}

Bu araştırmanın planlanması, veri toplama araçlarının oluşturulması, katılımcıların belirlenmesi, izinlerin alınması, görüşmelerin yapılması, veri toplanma süreci ve analiziyle bulgulara dönüştürülmesi ve son olarak raporlaştırılması bir öğretim üyesi ve üç öğretim elemanı tarafından gerçekleştirilmiştir. Araştırmacıların biri özel eğitim alanında doktora derecesine sahip öğretim üyesidir. İlk yazar yüksek lisans eğitimi tez aşamasında, ikinci ve üçüncü yazar doktora eğitimine devam etmektedir. Çalışmaya katkı sağlayan yazarların özel eğitim alanındaki mesleki kıdemleri 3-20 yıl aralığında değişmektedir. Araşıırma, salgın döneminde eğitim kurumlarının yüz yüze eğitime ara vererek evde online eğitim çalışmaları kapsamında sürdürülmesinin yanı sıra ailelerin çocuklarının eğitimlerine ilişkin deneyimleri temel alınarak planlanmıştır. Özellikle sağlık çalışanlarının iş yoğunluğu ve mesai saatlerindeki değişimlere bağı deneyimleri temel alınan çalışmanın planlanmasına yönelik adımlar şu şekildedir:

2020 Şubat ayı sonu ile Mart ayı içerisinde ulusal ve uluslararası alanyazında Koronavirüs salgını hakkında kaynak taraması yapılmış, ülkemizdeki eğitim, sağlık ve sosyal yaşama ilişkin resmi düzenlemeler incelenmiştir. Araştırmacıların görev dağılımları ise şu şekildedir: Alanyazın taramasında tüm araştırmacılar görev almış; ilk üç yazar görüşmelerin gerçekleştirilmesi, verilerin toplanması, verilerin bilgisayar ortamına aktarılması ve analizinde sorumluluk almıştır. Çalışmanın dördüncü yazarı olan öğretim üyesi alanyazın taraması, araştırmaya duyulan gereksinim doğrultusunda konu, yöntem ve içeriğin belirlenmesi, görüşme formunun hazırlanması, verilerin analizi, bulgulara dönüştürme ve 
Demiröz, Yıldırım Parlak, Küçük Karahan \& Kayhan - Çukurova Üniversitesi Eğitim Fakültesi Dergisi, 50(2), 2021, 749-777

raporlama sürecinde yer almış, çalışmanın koordine edilmesi, raporlama, bölümlerin son okumaları, düzenleme ve geribildirim verme sorumluluğu almıştır. Çalışma ekibindeki dört yazarın da, nitel araştırma yöntemlerine ilişkin ders deneyimleri ve akademik çalışmaları bulunmaktadır. Bu bağlamda araşıırma, dört yazarın her aşamada farklı düzeylerde sorumluluk aldığı bir ekip çalışması niteliğindedir.

\section{Kullanılan Veri Toplama Aracı}

Bu araştırmada özel gereksinimli çocuğu olan annelerin görüşlerine dayalı veri toplanması amaçlanmış, yarı yapılandırılmış görüşme tekniği kullanılmıştır. İlk olarak verilerin toplanması amacıyla:

Özel gereksinimli çocuğa sahip sağlık alanında çalışan annelerin çalışma koşulları ve yasal hakları incelenmiş̧tir.

a) Salgın sürecinde annelere ve çocuklarına yönelik yapılan düzenlemeler, sağlanan destekleri içeren alan araştırmaları incelenmiş; dört araştırmacı tarafından Şubat-Mart-Nisan (2020) ayında her hafta belirli saatlerde çevrimiçi tartışma oturumları düzenlenmiştir. Bu oturumlarda Sağlık Bakanlığı, Milli Eğitim Bakanlığı́nın yasal düzenlemeleri de dikkatle incelenmiştir.

b) Alanyazın taramaları sonucunda ülkemizde koronavirüs dönemine ilişkin sağlık çalışanı anneler ile gerçekleştirilmesi planlanan araştırmaya karar verilmiş; Mart ve Nisan (2020) ayı boyunca özel gereksinimli çocuk ile sağlık çalışanı anne kavramlarına odaklanılmışır. Bakım, eğitim, etkileşim, sosyal destekler, aile ortamı ve anne-çocuk yaşantıları irdelenmiştir. Sonrasında alanyazına dayalı görüşme sorularının yer aldığı havuz oluşturulmuş, bu sorular özel eğitim alanında erken çocukluk, eğitsel değerlendirme, aile ve öğretmenlerle çalışma deneyimi olan iki öğretim üyesi uzmanın görüşlerine sunulmuştur. Uzmanların sorular hakkındaki görüşleri, uygun, uygun değil, değiştirilmeli başıklarına dayalı olarak alınmıştır. Görüşme formuna ilişkin önerileri (soru sayısının azaltılması, çalışan anne kavramına yönelik ifadenin daha güçlü algılanabileceği sorularda sağlık çalışanı anne vurgusunun yapılması, çocuklarının Covid-19 döneminde eğitim ve bakım hizmetini sağlamak amaçı eş-aile yakını desteğinin detaylı ayrı bir soruda sorulması vb. öneriler) doğrultusunda, görüşme formunun son hali düzenlenmiştir. Formda iki bölüm yer almaktadır. Birinci bölümünde özel gereksinimli çocuğa ait demografik bilgiler, ikinci bölümünde ise sağılı çalışanı annelere yönelik kişisel bilgilerle görüşme sorularına yer verilmiştir. Görüşme formunda 10 açık uçlu soru bulunmaktadır (Tablo-2 Yarı yapılandırılmış görüşme soru formu). Araştırmanın planlama ve uygulama aşamasına yönelik Etik Kurul İzni bulunmaktadır. Etik kurul izni, Hasan Kalyoncu Üniversitesi Sosyal Bilimler Enstitüsü Etik Kurulu E-804.01-2011250028 sayılı kararı ile onaylanmıştır.

Tablo 2.

Yarı Yapılandırılmış Görüşme Soru Formu

Covid-19 Salgın Süresince Sağlık Çalışanlarından Özel Gereksinimli Çocukları Olan Ebeveynlerin Deneyimleri

Demografik Bilgi Formu

Çocuğun yaşı: $\quad$ Çocuğun cinsiyeti: $\quad$ Çocuğun Özel Gereksinim Alanı:

Ebeveynin yaşı:

Katılımcının çocuğa yakınlık derecesi: Yaşı:

COVID-19 süresince çalışma saati:

Cinsiyeti: Çalışma Durumu:

COViD-19 süresince çocuk ile kim ilgileniyor?

COVID-19 süresince ayrı konaklama yaptınız mı?

COVID-19 süresince özel eğitim hizmeti alıyor musunuz? Eğer alıyorsanız kim tarafından ve nasıl gerçekleşiyor?

\section{Görüşme Soruları}

1-Sağlık sektöründe hangi görevde çalışmaktasınız?

2-COVID-19 salgınında evden ayrı kaldığınız süreci ve öncesini anlatabilir misiniz?

3-COVID-19 sürecinde günlük rutinleriniz ve öncesine yönelik farklılıklar hakkında neler 
Demiröz, Yıldırım Parlak, Küçük Karahan \& Kayhan - Çukurova Üniversitesi Eğitim Fakültesi Dergisi, 50(2), 2021, 749-777

söyleyebilirsiniz?

4-COVID-19 süresince özel gereksinimli bir çocuğa sahip olmak yaşamınızı nasıl etkiledi?

5-COVID-19 sürecinde ÖG çocuğa sahip olan ebeveynlerin yasal hakları nelerdir? Salgın sürecinde bu haklardan yararlanmaya devam ettiniz mi?

6- Bu süreçte evinizden ayrı bir konaklama yaptıysanız bununla ilgili deneyimlerinizi anlatabilir misiniz?

7-Bu süreçte ev iklimi ve aile bireyleri ile olan iletişiminiz nasıl etkilendi? Yaşadığınız değişiklikler nelerdir?

8-Çalışma saatleri dışında çocuğunuz ile nasıl vakit geçirmeye çalışıyorsunuz?

9-Bu süreçte sizi en çok destekleyen kim ya da kimler oldu? Bu desteklerden kısaca bahsedebilir misiniz?

10-Evde özel gereksinimli bir çocuğunuz var ve salgının en yoğun olduğu/yaşandığı yerler hastaneler, bu durumda yaşadığınız duygulardan ve aldığınız önlemlerden bahsedebilir misiniz?

\section{Verilerin toplama Süreci-işlem}

Veri toplama süreci Koronavirüs (Covid-19) salgın sürecinde olduğundan, hem bulaş riskinin sağlığı tehlikeye atması hem de sokağa çıkma kısıtlamaları nedeniyle katılımcı annelerle telefonda görüşme yapılmışır. Görüşmelerden önce annelere uygun oldukları gün ve saat bilgisi sorularak görüşme randevusu oluşturulmuştur. Ayrıca yapılacak görüşmelerin kaydedilmesine yönelik izinleri alınmıştır. Görüşmeler yapılmadan önce araştırmacılar ilk olarak kendilerinin görüşme yapacakları ortamın uygun olmasına dikkat etmişlerdir. Bu doğrultuda ortamın sessiz olmasına dikkat etmiş ve görüşme sırasında yazılı not alabilecekleri araç-gereçleri hazır bulundurmuşlardır. Katıımcı annelere araştırma amacı tekrar hatırlatılmış, ses kaydı almak üzere onayları alınmıştır. Görüşme formundaki sorular annelere aynı sırayla sorulmuştur. Görüşmeler 05.05.2020-15.05.2020 tarihleri arasındaki 10 gün içinde yapılmıştır. Görüşmeler ortalama 11-25 dk (Toplam süre=127 dk) arasında sürmüş; etik unsurlar göz önünde bulundurularak annelere ve görüşmede bahsedilen aile üyelerine kod adlar verilmiştir.

Verilerin toplandıktan sonra görüşmelerin ses kaydı ve not dökümü öğretim elemanları tarafından bilgisayarda yazılı döküm şekline dönüştürülerek bir word dosyasına geçirilmiştir. Yapılan görüşmeler yazıya dönüştürüldükten sonra toplam, 74 sayfa veri elde edilmiştir. Yazılı dökümlerin ve notların doğruluğunu belirlemek amacıyla değerlendiriciler arası güvenirlik hesaplamak için üç görüşmenin yazılı dökümlerin ve ses kayıtlarının tutarlıı̆ı incelenmiş; inceleme sonunda yazılı dökümler/alınan notlar ve ses kayıtlarının yazıı dökümleri arasında bir fark bulunmadığı görülmüştür. Ardından verilerin analizi aşamasına geçilmiştir. Elde edilen verileri açıklamak ve kavramlara ulaşmak üzere içerik analizi yapılmışıı. İçerik analizi elde edilen verilerden ulaşılan kavramların ve verilerin açıklanmasına olanak tanıyan tema ve alt temaların ortaya konulmasıdır (Yıldırım ve Şimşek, 2018). Verilerin okunmasıyla tekrarlanan ifadeler belirlenmiş ve bu bağlamda kodlar ortaya çıkarılmıştır. Bu aşamadan sonra ilişkili kodlar birleştirilerek temalar ve alt temalara ulaşılmıştır. Yapılan içerik analizi neticesinde beş ana tema ile 27 alt tema ortaya çıkmıştır. Ulaşılan temalara yönelik gözlemciler arası güvenirlik çalışmaları iki araştırmacı tarafından yapılmıştır. Belirlenen kodlar, tema ve alt temalar için Miles ve Huberman (1994)'ın (Görüş birliği/Görüş Birliği + Görüş Ayrılı̆ı) x 100 formülü kullanılarak \%95 oranında görüş birliği elde edilmiştir (Miles ve Huberman, 1994).

\section{Bulgular}

Özel gereksinimli çocuğu olan sağlık çalışanı annelerin görüşme sorularına verdikleri cevapların analiz edilmesiyle ulaşılan bulgulara bu başlıkta yer verilmiştir. Bulgular, annelerin Covid-19 sürecinde ev ve iş deneyimlerine ilişkin görüşlerini içermekte, beş ana tema ve 27 alt temadan oluşmaktadır. Veriler, ana tema ve alt temalarına göre tablolaştııılmıştır. 


\section{Ana Tema: Çalışma Koşulları}

Tablo 3.

Çalışan Annelerin İ̧ Deneyimleri

\begin{tabular}{cl}
\hline \multicolumn{1}{c}{ Ana Tema } & \multicolumn{1}{c}{ Alt Tema } \\
\hline & 1-Çalışma günleri ve saatlerindeki değişim \\
& 2-Risk grubu ile çalışma \\
Çalışma Koşulları & 3-İzin haklarının kaldırılması \\
& 4-Sağlık Hizmetleri Birimine göre çalışma koşulları \\
& 5-Iş ortamındaki iş birliği \\
6-Destek görememe
\end{tabular}

Sağlık çalışanı anneler, Covid-19 sürecinde çalışma koşullarında farklılıklara dikkat çekmiş, yoğun mesai saatleri olduğunu belirtmişlerdir. Bu değişimler çalışma günleri ve nöbetlerini, mesai saatlerini kapsamaktadır. Ayrıca mesaideki geçen sürede yoğunluk yaşadıklarını dile getiren katılımcılar; özellikle yaşlı hastalarla çalışma durumlarında artış yaşadıklarını ifade etmişlerdir. Örneğin, Su: Günde 25 vaka. Çalışma saatlerim 24 saat 72 gün. Ama şimdi çok fazla belli olmuyor. Bu ay 17 nöbetim var. Mesai almak isteyen alırdı ama şimdi mecbur 1314 nöbet oluyor. Zor bir süreç, şeklinde görüş bildirirken; Rüya: Aynı mesaimizi çalışıyoruz. Yani normalde esnek çalışma dendi ama biz üniversite hastanesi olarak yani aynı mesai saatimizi çalışıyoruz, diyerek çalışma şartlarında düzenleme yapılmadığını belirtmiştir. Fatma ise: Bizim birime çok yaşlı geliyor, engelli geliyor. Korkuyoruz, diyerek risk grubundaki bireylerle çalışmanın zorluğuna dikkat çekmiştir.

Rüya: IIlk başlarda ben izin aldığımda hani çocuğum rahatsız diye ben işte hatta şey 1 I,.. O raporda hatta beni idare çağırdı hani, gerçek mi değil mi? Hani bak gerçek değilse söyle..... Hani ona bile inanmadılar yani biz öyleydik, o izni bile almamı istemediler, şeklinde iş yaşamına bağlı izin ve yasal haklarını kullanmada yaşadığı zorlukları ifade etmiştir. Ayrıca anneler ev ortamında çocuklarına yeterince vakit ayıramadıklarını, işe geldiklerinde tükenmişlik, kaygı ve stres düzeylerinde artış meydana geldiğini ifade etmişlerdir. İ̧̧ arkadaşlarından salgın döneminde daha yoğun anlayış, sosyal destek ve iş birliği beklentisinde olduklarına vurgu yapmışlardır. Örneğin Rüya, Diyorum benim çalışmamam gerekiyor. Hani çalışmam. Benim yasal hakkım böyle böyle. Hani işte yasada yazıyor mu? Hangi genelgede? Yasayı getir. Hatta ben yasaları falan başhemşireliğe götürdüm. Dedim burada bu yazıyor burada da bu yazıyor, diyerek iş ortamında yaşadığı süreci, iletişim zorluklarını ifade etmiştir. Emine ise: Gece nöbetlerine dönüldüğü için benim çocuğum da küçük olduğu için sen çık çocuğu küçük olmayan başka bir arkadaş girsin dediler. Ben çıktım sonra labaratuvardan ama yine destek veriyorum, şeklinde görüş bildirerek Rüya'nın tam tersine iş ortamında yasal düzenlemeye bağlı aldığı sosyal desteğin önemine vurgu yapmıştır.

\section{Ana Tema Ortaya çıkan gereksinimler}

Tablo 4.

Çalışan Annelerin Gereksinimleri

\begin{tabular}{ll}
\hline \multicolumn{1}{c}{ Ana Tema } & \multicolumn{1}{c}{ Alt Tema } \\
\hline & 1. Yasal hakları bilme ve yasal haklara erişim \\
gereksinimi & \\
Ortaya Çıkan Gereksinimler & 3. Aile eğitimine duyulan gereksinim \\
& 4. Eğitim ve destekleyici uygulamalara yönelik maddi \\
gereksinim
\end{tabular}

Çalışmanın ikinci ana temasında çalışan annelerin gereksinimleri, hem mesleki açıdan hem de evde bakımlarını üstlendikleri çocukları açısından zor bir süreç yaşadıklarını göstermiştir. Anneler iş ve ev yaşamı olmak üzere, her iki alanı kontrol altına alabilmek için kendilerinden ödün verdiklerini belirtmişlerdir. Rüya: Ben şey olarak talep ettim hastaneden idari izinli sayılmamız konusunda talep ettik. Özel çocuğumuz olduğu için. Onlar da olumsuz geri döndüler. Yani mecbur hatta, ben daha iyi bir serviste çalışıyordum. Daha rahat diyeyim. Beni acile çektiler. Hem daha yoğun çalıştım öyle diyeyim, sözleriyle 
Demiröz, Yıldırım Parlak, Küçük Karahan \& Kayhan - Çukurova Üniversitesi Eğitim Fakültesi Dergisi, 50(2), 2021, 749-777

süreçte yaşadığı zorluğu özetlemiş; Hülya ise: Yani çalışma arkadaşlarımız ben olmadığımda arkadaşlarım beni destekliyor, onlar olmadığında ben onları destekliyorum o şekilde hiçbir sorun yok yani. Beni bir onlar anlıyor, diyerek çalışma koşullarında çalışma arkadaşları dışında yeterli destek görmediğini belirtmiştir. Gamze: Bu süre içerisinde, şu anda babayla beraberler dönüşümlü şey yapıyoruz. Hani baba bekliyor ben geliyorum, ben geldikten sonra baba işe gidiyor. Babanın işi özel sektör olduğu için. Başka destek yok, şeklinde görüş bildirerek destek ihtiyaçlarına dikkat çekmiştir. Fatma'nın çocuk bakımına ilişkin görüşü: Benim kimsem yok, ortadayım, bakıcım bakıyor. Eşim, kızım tanı aldıktan sonra bizi terk etti, anne olarak tekim. Ben ne yapabilirim? şeklinde yaşadığı zorluğa dikkat çekmiştir. Eşi ile ayrılmasına bağlı tek ebeveyn olduğunu ve Covid-19 boyunca bu durumun dikkate alınmadığını ifade eden Fatma: Izinler reddediliyor, yasal hakkımızı bilmiyoruz. Bir nöbeti biliyorum. Onun dışında ne hakkımız, bilmiyorum. Ulaşamıyoruz. Çocukların eğitimi için çalışmalıyım. Eğitimler çok pahalı. Çalışmayayım diyorum çocuklara bakan yok ama mecburum. Eğitimleri geride kalmasın diye çalışıorum, ifadeleri ile salgın süreci öncesinde de yaşadığı ekonomik ve sosyal güçlüklere vurgu yapmıştır.

\section{Ana Tema: Covid-19 ile Değişen Yaşam Tarzları}

Tablo 5.

Covid-19 Etkileri

\begin{tabular}{cl}
\hline \multicolumn{1}{c}{ Ana Tema } & \multicolumn{1}{c}{ Alt Tema } \\
\hline & 1.Psikolojik süreçler \\
& 2.Günlük rutinlerdeki değişim \\
& 3.Teknoloji kullanımındaki artış \\
Covid-19 ile Değişen Yaşam Tarzları & 4.Güvenlik becerilerinin önemi \\
& 5.Virüs ile ilgili kaygı \\
& 6.Sosyal hayatın kısıtlanması \\
& 7.Yeme alışkanlıklarındaki değişim \\
\hline
\end{tabular}

Çalışmanın üçüncü ana temasında anneler Covid-19 ile birlikte hayatlarındaki değişen rutinler ve alışkanlıklara dikkat çekmişlerdir. Evde kalma süresinin artmasıyla aynı oranda evde ve işte bütün sorumluluğu üstlenmelerine bağlı kaygı yaşadıklarını bildirmişlerdir. Bu süreçte çocuklarının bakımı ve güvenliği konularında kaygı yaşadıklarına dikkat çeken anneler, bu kaygıya neden olan kaynakları ise güvenlik becerileri, virüsü ev halkına bulaştırma korkusu olarak belirtmişlerdir. Ayrıca akraba ziyaretlerine gidememeye bağlı yalnızlık duygusu ile evde kalınan dönemde fiziksel aktivite kısıtılığı yaşadıklarına, yeme bozukluklarındaki artışa da vurgu yapmışlardır.

Emine: Ben laboratuvarda çalışmaya başlayınca babaannesi bizde yaşamak zorunda kaldı. Çünkü çocuğu ben kucağıma alamayacağım için temizlik dezenfeksiyon süreci geçirmemiz gerekiyordu. Çocuğu kucağıma alabilmek için bile elimi yüzümü yıkayıp temizlemem gerekiyordu, diyerek süreç içinde yaşanan ev yaşamındaki değiş̧ikliğe ve virüsü çocuğuna bulaştırma korkusuna değinmiştir.

Fatma: Az çıkarıyordum, Çok az çıkarıyordum. Çünkü daha tam olarak hani farkında değil bir de elimizi bırakıp koşmak istiyor düşüyor, kalkıyor ya da kaçmak istiyor elimizden, ..daha tam olarak bilmiyor, şeklinde görüş bildirmiş, özel gereksinimli çocuğunun güvenlik becerilerindeki gelişimi ile sosyal yaşamda tedirginlik yaşadığını açıklamıştır. Su: Ne kadar 1, 2'ye kadar yatmadığı oluyor. Tabii ki yani bütün çocukları da bizi de etkiledi bu süreç. Işste bizim ayrıca hani bulaştırır mıyız korkusu tamamen psikolojik olarak yıprandık diyebilirim, şeklinde görüş bildirmiş ve bulaşma riski ile ilgili süreçteki korkularını ifade etmiştir. Duygusal tükenmişliklerine de dikkat çeken annelerden Fatma: Depresyona girdim, kalp atışım yükseldi. Baya zorlandım. Virüsü bulaştırır mıyım diye çok tedirgin oldum. Biraz etkilendim. Evden işe, işten eve, sosyal yaşam yok. Her şey sana bakıyor, diyerek yaşadığı sürecin kendisinde bıraktığı etkilere dikkat çekmiştir. 
Demiröz, Yıldırım Parlak, Küçük Karahan \& Kayhan - Çukurova Üniversitesi Eğitim Fakültesi Dergisi, 50(2), 2021, 749-777

IV. Ana Tema: Annelerin Çevrimiçi Eğitime Yönelik Deneyimleri

Tablo 6.

Annelerin Çevrim içi Eğitime Yönelik Deneyimleri

\begin{tabular}{cl}
\hline Ana Tema & \multicolumn{1}{c}{ Alt Tema } \\
\hline & 1- Kurumlardan desteğin olmaması \\
& 2- Öğretimsel uyarlamaların olmaması \\
& 3- Genel eğitim öğretmenlerinin desteğinin olmaması \\
Çevrim içi Eğitime Yönelik Deneyimler & 4- Ailelerin farkındalığının artırılması \\
& 5- Online eğitimin yetersiz olması \\
\hline
\end{tabular}

Çalışmaya katılan annelerin Koronavirüs (Covid-19) sürecinde yaşadıkları zorluklardan bir diğeri ise çocuklarının eğitim gereksinimlerini karşılama konusudur. Annelerin belirttiği zorluklar sırasıyla özel gereksinimli çocuklarının eğitimden geri kalması, salgın öncesi geldikleri noktadan daha ileriye gidememeleri, kurumların bu süreçte gerekli desteği göstermemesi ve aile olarak kendilerinin online eğitimler hakkında bilgi gereksinimlerinin karşılanmamasıdır. Fatma: Biz kurumdan destek alıyoruz, haftada bir kez ama bu yeterli değil. Ben nasıl yapacağımı bilmiyorum. Problem davranış gösteriyor. Nasıl destekleyeceğimi bilmiyorum, görüşü ile süreçte çocuğuna beceri ve davranışları nasıl öğreteceğine yönelik desteğe gereksinim duyduğunu belirtmiştir. Emine: Eğitimi hakkında çok fazla gereksinime ihtiyaç duyuyoruz, bu bilişsel anlamda okul çok fayda sağlıyordu. Ben okulun gerekli önlemler alındıktan sonra başlamasından yanayım. Çünkü her ödevi benim çocuğum yapamaz, şeklinde görüş bildirerek özel gereksinimleri olan çocuklara öğretimsel uyarlama yapılıp gelişimlerine göre desteklenmesi gerekliliğini vurgulamıştır. Gamze: Kaynaştırmaya devam ediyor, Yani şu şu kitaptan, II diyelim ki matematik kitabı bilmem kaçıncı sayfadan şu yapılacak işte bana video atacaksınız. Şu şiir okunacak, okurken bana video atacaksınız öyle şeyler mesajlar atıyor. Nasıl yapacağız? görüşünü ifade etmiş; desteğin ve öğretimsel uyarlamanın yetersiz olduğunu belirtmiştir. Su: Eğitim videosu atıyorlar, şöyle yapın. Yapıyoruz olmadı, nasıl yapacağımı öğretilmedi ki. Uzaktan online ile özel eğitim olmaz, çok zor, görüşü ile online eğitimde istenilen verim, yönlendirme ve dönütleri alamadıklarını bildirmişlerdir.

V. Ana Tema: Görüş ve Öneriler

Tablo 7.

Annelerin Görüşleri ve Önerileri

\begin{tabular}{|c|c|}
\hline Ana Tema & Alt Tema \\
\hline \multirow{5}{*}{ Görüş ve Öneriler } & 1-Kurumların eğitim hizmetleri sunmakta yetersiz kalması \\
\hline & 2-Öğretmen yeterliliklerinin artırılması \\
\hline & 3-Özel eğitimin niteliğinin artırılması \\
\hline & 4-Yüz yüze eğitim isteği \\
\hline & $\begin{array}{l}\text { 5-Çalışan ebeveynlere tanınan } \\
\text { genişletilmesi }\end{array}$ \\
\hline
\end{tabular}

Annelerin görüş ve önerileri genellikle çocuklarının ihtiyaçlarının giderilmediği yönündedir. Görüşleri incelendiğinde, çocuklarının eğitimi ve bakımı konularında yaşanan kaygılar öne çıkmaktadır. Bu konuda Fatma: Herkes farkında olsa yani kurumlar da ticari amaç gidiyorlar. Hani hocalar daha fazla donanımlı bizi daha çok fazla desteklese daha fazla donanımlı olsa dil ve konuşma anlamında daha çok bilgiye sahip olsa, daha çok hani bize yol gösterseler, diyerek kurum, eğitim ve öğretmen niteliklerinin artırılması gerektiğini ifade etmiştir. Annelerin üzerinde durduğu önemli noktalar: İ̧̧ yükünün azaltılması, evden destek sağlama, yasal haklarının düzeltilmesi, çocuklarının bakımlarının ve eğitimlerinin zorda kalmadan devam etmesi yönündedir. Bunun için önerileri incelendiğinde, yasal düzenlemeler yapılması ve uygulama farklılıklarının önüne geçilmesidir.

Sağlık çalışanı ve özel gereksinimli çocuğu olan annelerin Koronavirüs sürecinde yaşadıklarına odaklanılan bu araştırma sonucunda, annelerin aile içi rol ve sorumluluklarının artış gösterdiği, yoğun bir biçimde üstlendikleri bu sorumluluklara bağlı kaygı yaşadıkları dikkati çekmektedir. Annelerin birçok 
sorunla çoğu kez yalnız baş etmek zorunda kaldıkları, hem iş yaşamı hem de evdeki sorumluluklarını gerçekleştirme noktasında desteğe gereksinimlerinin olduğu sonucuna ulaşılmıştır.

\section{Tartışma ve Sonuç}

Bu araştırmada, özel gereksinimli çocuğu olan sağlık çalışanı annelerin Koronavirüs (Covid-19) sürecinde iş, ev yaşamı deneyimlerine ilişkin görüşleri, derinlemesine betimlenerek incelenmiştir. Çalışma Koşulları Temasında (Tema 1) anneler, Covid-19 süreci ile birlikte değişen çalışma yaşamlarına dikkat çekmişlerdir. Anneler çalışma saatlerindeki değişiklik ve risk gruplarıyla çalışma sürelerindeki artışa dikkat çekmiş, izin haklarının kaldırılması ve sağlık hizmetleri birimine göre çalışma koşullarındaki değişimleri vurgulamışlardır. Çalışma koşullarının düzenlenmesinde çocuklarının özelliklerinin ve aile ortamlarının dikkate alınması beklentilerini, ayrıca iş ortamında sınırlı iş birliği ve destek görememe gibi sorunlarla baş etmek durumunda kaldıklarını ifade etmişlerdir. Bu süreçte annelerin en çok tedirgin oldukları konu virüsü ailelerine bulaştırmak ve önlem alabilmede geç kalma veya yeterli önlem alamama konusudur. Alan yazında da benzer bulgulara rastlanılmıştır (Baki ve Piyal, 2020; UNICEF, 2020a). UNICEF tarafından, Covid-19 döneminde yetişkinlerin aile içinde bağışılık sistemlerinin düşük olduğu gerekçesi ile özel gereksinimli çocukları için daha tedirgin oldukları belirtilmektedir. UNICEF (2020a)'in yayınlamış olduğu raporda belirtildiği üzere Covid-19, altta yatan bazı sağlık sorunları nedeniyle özel gereksinimli çocukları enfeksiyon kapma ve ağır hastalığa yakalanma konusunda daha yüksek risk altında bırakmıştır. Baki ve Piyal (2020)'in gerçekleştirdiği çalışmada sağlık çalışanlarının bu süreçten çok etkilendikleri ve evde birlikte yaşadıkları bireylere virüsü yayma korkuları olduğu belirtilmiştir. Ayrıca bu bulgu, pandemi ile birlikte annelerin artan çalışma koşulları, iş-ev yüklerinin artışı ve aile içi çatışmalar yaşamalarına yönelik alanyazın bulgularıyla benzerlik göstermektedir. Anneler çalışma ortamında iş arkadaşlarından destek gördüklerini belirtirken, çok azı destek görmediklerini bu durumun da kendileri için zorlayıcı olduğunu ifade etmiştir. Bu sonuç ile örtüşen bir diğer araştırma bulgusu UNICEF (2020b)'in Koronavirüs salgınında çalışan ebeveynlere destek olunmasına dikkat çekilen araştırmadır. UNICEF (2020b) araştırma sonucunda, işverenlere yedi öneriden oluşan bir rapor sunmuştur. Raporda özellikle kadınların erkeklerden daha çok sorumluluk üstlendiğinde dikkat çekilmiş (iş yaşamı, ev yaşamında denge rolü) bu nedenle işyerlerinde, çalışan annelerin aldığı kararlardan dolayı izin kullanma veya nöbet dağııımı gibi durumlarda cezalandırıcı muameleden korunmasına vurgu yapılmışır. Anne olan çalışanların, korunmasına yönelik önlemler alınması gerektiği belirtilmiştir. Çünkü salgın döneminde çalışan annelerin büyük kısmı iş yerlerinde korunurken (işten çıkarmama, ayrımcı davranışa maruz kalmama vb.), bir kısım annenin cezalandırıcı muameleye maruz kaldığı ifade edilmiştir.

Tema 2'de pandemi ortamında anneler ve çocukları için birtakım gereksinimlerin daha ön plana çıktığı belirlenmiştir. Anneler için özel gereksinimli çocukların eğitimleri ve bakımları nedeniyle evde onlarla birlikte olmak, aynı zamanda maddi nedenler dolayısıyla iş hayatlarına devam etmek gibi gereksinimler yoğunluk göstermiştir. İş hayatında sorumlu oldukları işveren ya da yöneticilerin özel gereksinimli çocuğu olan annelerin ihtiyaçlarını dikkate almadığı durumlarda; iş yükünü daha da ağırlaştıran sorunlar ile baş başa bırakıldıkları sonucuna ulaşılmışır. Anneler bu sorunları tanımlarken; yasal haklarıyla ilgili bilgi edinme, yasal haklarını kullanma, yetkililere bilgilendirme yapılması, yasaların ulaşılabilir ve erişilebilirliği, kadın yöneticinin olumlu etkisi ve idari izinli sayılma talebi şeklinde tanımlamışlardır. Bu bulguyu destekler nitelikte bir araştırma Yıldırım ve Hacıfazlığlu (2019)'na aittir. Yıldırım ve Hacıfazlığlu (2019) çalışan annelerin iş hayatına devam gerekçesinin maddi zorluklardan kaynaklandığııı; iş yaşamında yasal haklarını kullanamamalarını ve yöneticileriyle sorun yaşamakta olduklarını ifade etmişlerdir. Bu sonuç, araştırmanın bulguları ile benzerlik göstermektedir. Tipik gelişim gösteren çocuğu olan sağlık çalışanlarıyla gerçekleştirilen bir diğer çalışmada yasal izinleri olduğu halde personelin, idareciler tarafından izin haklarını kullanmalarına izin verilmediği ve çalışanların idareciler tarafından bir takım baskılarla karşılaşabildikleri belirtilmiştir (Nakış̧̧i, Kavas ve Develi, 2020). Buna göre çocuğu olan çalışan anneler ve özel gereksinimli çocukları için sürecin daha karmaşık olduğu sonucuna varılabilir. Ayrıca bu araştırmada yer alan sağlık çalışanı anneler salgının devamına bağlı kurumların kapalı olmasından dolayı, çocuklarının eğitimlerini sıklıkla kendilerinin üstlendiklerine vurgu yapmışlardır. Bu süreçte çocuklarını evde desteklemek amaçı aile eğitimi gereksinimi ortaya çıkarmışır. Yapılan çalışmalarda annelerin çoğunlukla intiyaç duydukları konuların başında, çocuklarının 
gereksinimlerine uygun aile eğitimlerinin verilmesi gelmektedir (Toy ve Kesici, 2020). Pandemi sürecinde kurumların kapalı olmasından dolayı aile destek görememekte ve ortaya çıkan sorunlarla baş etmekte zorlanmaktadır (Akoğlu ve Karaaslan, 2020). Karahan, Demiröz, Yıldırım ve Özaydın (2020), benzer şekilde Covid-19 sürecinde öğretmen ihtiyaçlarını belirlemek için gerçekleştirdikleri çalışma sonucunda, aileler ve öğretmenlerin aile eğitimlerinin artırılması ve kendilerine geri bildirim verilmesi yönünde gereksinimleri olduğunu belirtmişlerdir. Covid-19 sürecinde aile ihtiyaçlarının belirlenmesi üzerine gerçekleştirilen bir başka çalışma Yıldırım, Karahan, Demiröz, Şener ve Özaydın'a aittir (2020). Çalışan anneler, çocukları için bakım desteği ihtiyacının arttığını ve zor bir süreç geçirdiklerini belirtmişler; çocuk bakımı desteği ve günlük bakım hizmetlerine ihtiyaç duyduklarını ifade etmişlerdir. Sağlık çalışanı annelerin yasal haklarını kullanamamaları vb. gibi çalışma koşullarından dolayı stres yaşayarak mesleklerinden vazgeçme düşüncesine sahip olma bulgusu ise İmirlioğlu (2009) tarafından yapılan çalışmanın bulgusu ile paralellik göstermektedir.

Tema 3'de, anneler Covid-19 sürecinde değişen yaşam tarzlarını psikolojik süreçler, çocuk ve ev yaşamına ilişkin rutinler, teknolojinin yaşama girmesi, güvenlik becerilerinin önemi, virüs ile ilgili kaygı, sosyal hayatın kısıtlanması, yeme alışkanlıklarındaki değişim olarak betimlemişlerdir. Annelerin bu süreçte artan iş yükü ve özel gereksinimli çocuğunun gereksinimlerini karşılamada yalnızlık duyguları, psikolojik tükenmişlik yaşadıkları dikkati çekmiştir. Değişen rutinler, çocukları ile evde geçirilen zamanın azalması ve izin haklarının kaldırıması, annelerde psikolojik baskı yaratmıştır. Salgın nedeniyle evde kalma süresinin uzaması ve sosyal izolasyon gereği toplu alanlara çıkılamaması, anneler için süreci daha da zorlu bir hale dönüştürmüştür. Bunun sonucunda gündelik yaşamdaki hareketliliklerinin azaldığı ve ev içinde yeme alışkanlıklarının değiştiğini belirtmişlerdir. Anneler ile yapılan benzer bir çalışmada, Covid-19 sürecinde annelerin tükenmişlik yaşadıkları, diyetisyen yardımına ihtiyaç duydukları ve sosyal hayatlarının kısıtlandığı ifade edilmiştir (Yıldırım ve diğerleri, 2020). Nakışçi, Kavas ve Develi (2020)’ye ait kadın sağlık çalışanları ile ilgili çalışmada da anneler, çocuk bakımlarının, ev işi yüklerinin kendilerinde olduğunu ve bu nedenle iş yaşam dengesi kurmakta zorlandıklarını ifade etmiştir. Ameias, Lai, Mulsant ve Szatmari (2020) benzer şekilde araştırmalarında Covid-19 sürecinde değişen rutinlerin annelerin ev içi düzenlemeler yapması, güvenlik önlemlerine dair tedbirler almasını gerektirdiğini buna bağlı annelerin yeni rutinler için destek ihtiyaçlarının arttı̆̆ını ifade etmişlerdir.

Tema 4'te ise; anneler çocuklarının eğitimine yönelik bu süreçte kurum ve öğretmenlerden yeterli desteği göremedikleri ve çevrimiçi eğitimden bekledikleri düzeyde yararlanamadıkları üzerinde durmuşlardır. Alanyazında, Covid-19 sürecinde dezavantajlı grupların daha fazla etkilendiği, eğitimlerden yeterince yararlanamadığı, ailelerin öğrenmeyi destekleyici yeni rol ve sorumluluklar üstlendikleri vurgulanmaktadır (Birleşmiş Milletler Raporu, 2020; Bozkurt, 2020). Göl-Güven ve diğ. (2020) annelerin, çocuklarının bireysel farklılıkları göz önünde bulundurulmadan sunulan çevrimiçi eğitimlerde evde kendilerinden beklenen uygulamalar hakkında geri bildirim alamadıklarında; çocuklarının eğitimlerine yönelik kaygı duyabileceklerine vurgu yapmışlardır. Özellikle uzaktan eğitimde özel gereksinimli çocukların yararlanamadığı ve ihtiyacı karşılamadığı ifade edilmiştir. Alanyazında yer alan Covid-19'un ve gelecekteki pandemi gibi benzer süreçlerin olumsuz etkilerini azaltmak veya önlemek için uzaktan verilecek hizmetlere erişimin artırılması; teknolojik araç-gereçlerin ailelere sağlanması gerekliliği ifade edilmiştir (Amaral ve Vries, 2020; Ameias, Lai, Mulsant ve Szatmari, 2020). Bu bulgular, çalışmada annelerin vurguladığı noktalarla benzerlik göstermektedir. Covid-19 salgını herkes için, özellikle de rutinleri bozulan, değişimler yaşayan ve eğitimden uzak kalan çocuklar ve aileler için yaşamı zor bir hale dönüştürmüştür. Eğitim öğretim süreçlerinden uzun süre ayrı kalmak özel gereksinimli çocukları olan ailelerin eğitime dair kaygılarını artırmıştır. Görüşmelerde annelerin de belirttiği gibi sunulan çevrim içi eğitimin yetersiz olduğu durumlarda, anneler çocuklarının eğitimine dahil olamadıklarını ve bilgilerinin yetersiz kaldığını belirtmişlerdir. Eğitim anlamında çocuklarına istedikleri katkıyı sunamamaları, annelerin çocuklarının eğitimiyle ilgili endişelerini de artırmıştır. Tüm bu bulgulardan yola çıkarak ailelerin eğitime ve desteğe gereksinim duydukları sonucuna varılabilir. Birçok kuruluş özellikle ailelerin bu süreci kaygısız geçirmeleri gerektiğine vurgu yapmış, bu nedenle iyi oluşlarını artırmak için destek sunmaya çalışmıştır. Örneğin özel gereksinimli çocuklar ile ilgili maske kullanımı, hijyen kurallarının öğretildiği web siteler tasarlanmıştır; aile eğitimleri ve bilgilendirmeler yapılmış; süreci daha iyi geçirmelerine yönelik çevrimiçi 
Demiröz, Yıldııım Parlak, Küçük Karahan \& Kayhan - Çukurova Üniversitesi Eğitim Fakültesi Dergisi, 50(2), 2021, 749-777

destekler sunulmuştur (Europen Communities Trade Mark Association [ECTA], 2020; The University of North Carolina at Chapel Hill [UNC], 2020).

Sonuç olarak bireyin gereksinimlerini aile bütünlüğü içinde değerlendirerek sağlanan destekleyici eğitimler, çocuklar ve aileleri için süreci kolaylaştırmaktadır. Bu anlamda özel gereksinimli çocuğa sahip ailelerin, destekleyici eğitime ulaşmaları önem taşımaktadır. Süreçte büyük bir rolü olan öğretmenlerin ve diğer özel eğitim paydaşlarının da nitelikli mesleki becerilere ve iş birliği yeterliklerine sahip olması gerektiği düşünülmektedir (Mereoiu, Abercrombie ve Murray, 2016; Olçay-Gül, 2014). Yapılan çalışmalarda, genel eğitim öğretmenlerinin çocuklara eğitim sunarken öğretimsel uyarlamaları nasıl yapacaklarını bilmemeleri desteklerin istenilen düzeyde olmadığını göstermektedir (Aydın ve Tuğluk, 2020; Sönmez, Alptekin ve Bıçak, 2018). Bu süreçte öğretmenlerin de özel gereksinimli çocuklarla neler yapacakları konusunda desteğe gereksinimleri, önemli bir boyuttur. Ayrıca bir başka çalışmanın (Karahan, 2019) sonuçlarında ebeveynlerin, genel eğitim sınıfındaki öğretmenlerin mesleki yeterliliğe sahip olmamaları durumunda çocuklarla ilgilenme ve bilgi paylaşımında bir takım sınılılıklar yaşandığı belirtilmiştir. Bu bulgu araştırma bulgusu ile benzerlik göstermektedir. Son olarak bu çalışmaya katılan annelerin görüşleri ve önerileri çocukları için düzenlemelerin gerekli olduğuna işaret etmektedir. Ortak görüşler annelerin çocuklarının özel eğitimden geri kalmamalarını istemeleri ve yüz yüze eğitime geçilmesi yönünde yoğunlaşmışır. Ayrıca sürece ve ilerleyen zamanlara yönelik kaygı düzeylerinin de yüksek olduğu görülmüştür. Bir yandan sağlık riski diğer yandan ev ve çocukların sorumluluğunun artmasına bağlı stres ve kaygı yaşayan annelerin, Covid-19 sürecinde iş ortamında yaşadıkları sorunların temelinde çocuklarının gereksinim türü, derecesi ve bakım sorumluluklarıın dikkate alınmaması gelmektedir. Çünkü anneler bu süreçte eğitim ve bakım kurumlarının kapalı olduğunu, salgın riski nedeniyle de yakın akraba, büyükanne, büyükbabadan bakım desteği alamadıklarını vurgulamışlardır. Oysa aile ve çevreyle yeterli iletişim içinde olma, ilişki kurma ve onlardan destek alma, stresten koruyucu faktörler arasında yer almaktadır (Milli Eğitim Bakanlığı, 2020). Anneler yukarıda da yer aldığı gibi bu faktörlere yeterli düzeyde erişemediklerini belirtmişler, dolayısıyla yeni normale ilişkin düzenlemelerde yasal haklarının iyileştirilmesi, hem çocuklarının bakım, eğitim ve sağlıklarını inmal etmeden hem de kendi iş yaşamı ve ebeveyn rollerinde iyi olma durumlarının korunarak iş ortamlarına katıımlarını sağlayııı düzenlemeler yapılmasına vurgu yapmışlardır.

\section{Öneriler}

$\mathrm{Bu}$ araştırmanın sonuçlarına dayalı olarak kurum yetkililerine yönelik öneriler: iş̧ yerinde idareciler, okulda öğretmenler ve müdürler öğrenci velilerinin eğitime katıımını sağlayıcı olumlu destek süreçleri planlayabilirler. Covid-19 salgını ve benzeri doğal afet, salgın gibi durumlara yönelik hazırıklar anlamında çocukların desteklenmesi, eğitimlerinin sürdürülmesi anlamında el kitapçıkları (basılı ve dijital) hazırlanarak velilerle paylaşılabilir. Aile katıımını temel alan düzenlemeler planlanabilir. Çalışan annelerin mobil uygulama aracılığı ile çocuğunun eğitimi hakkında öğretmen ile işbirliği yapması amaçlı kurumsal politikalar izlenebilir. Bu konuda MEB ile işbirliği yapılarak, EBA ve diğer bilişim platformlarının aileler tarafından aktif kullanımına dayalı süreç izlenebilir. Mobil uygulamaların eğitim amaçı içeriklerle desteklenmesi sayesinde, aileler bir yandan iş yaşamına devam ederken bir yandan da planlı bir biçimde evde çocuklarını destekleme noktasında olumlu bir süreç izleyebilirler. Aileler için geri bildirimlerin verilmesi adına, gerektiğinde yüz yüze gerektiğinde mevcut koşulları dikkate alarak, çevrimiçi ortamlarda uzman-öğretmen-ebeveyn katılımlı paylaşımlar, etkinlikler düzenlenebilir. Daha geniş ölçekte büyük örneklemleri içeren nicel araştırmalar planlanabilir, öğretmen, ebeveyn ve öğrenci görüşlerinin alındığı, deneyimlerine dayalı yansıtmalar yapabilecekleri odak grup görüşmeleri gerçekleştirilebilir. Sağlık kurumları yöneticilerinin katılımı ile Covid-19 döneminde sağlık hizmetlerinin planlanması ve personel memnuniyetini, gereksinimlerini içeren çalışmalar planlanabilir. Eğitim kurumları yöneticilerinin Covid-19 sürecinde uzaktan eğitime ilişkin görüş ve deneyimleri, ailelerle işbirliği boyutu incelenebilir.

“Yükseköğretim Kurumları Bilimsel Araştırma ve Yayın Etiği Yönergesinde' yer alan tüm kurallara uyulmuş ve yönergenin ikinci bölümünde yer alan "Bilimsel Araştırma ve Yayın Etiğine Aykırı Eylemlerden" hiçbiri gerçekleştirilmemiştir. 


\section{References}

Akoğlu, G. ve Karaaslan, T.B. (2020). COVID-19 ve izolasyon sürecinin çocuklar üzerindeki olası psikososyal etkileri. İzmir Kâtip Çelebi Üniversitesi Sağlık Bilimleri Fakültesi Dergisi, 5(2), 99-103.

Amakiri, C. P., Chude, C. F., Oradiegwu, U. O., Pramanik, I., Anoka, C. F. \& Ezeoke, A. Q. (2020). Psychological effect of pandemic Covid-19 on families of health care professionals. British Journal of Psychology Research, 8(2), 1-7.

Amaral, D. G. \& Vries, P. J. (2020). COVID-19 and Autism Research: Perspectives from Around the Globe. Autism Research, 13(6), 844-869. doi:10.1002/aur.2329

Ameias, S.H, Lai, M.C., Benoit H. Mulsant, B.H. \& Szatmari, P. (2020). Coping, fostering resilience, and driving care innovation for autistic people and their families during the COVID-19 pandemic and beyond. Molecular Autism, 11, 61. https://doi.org/10.1186/s13229-020-00365.

Aydın, D. ve Tuğluk, M.N. (2020). Okul öncesi öğretmenlerinin öğrenme-öğretme sürecinde öğretimsel uyarlamalara yer verme düzeylerinin belirlenmesi. Ulakbilge Sosyal Bilimler Dergisi, 47, 423-433. doi: 10.7816/ulakbilge-08-47-04

Baki, S. ve Piyal, B. (2020). Covid-19 pandemisi ve benzeri olağanüstü durumlarda sağlık çalışanları açııından iş-aile çatışması. Sağlık ve Toplum Dergisi, 119-123.

Birkan, B. (2001). Küçük Adımlar Kursu'nun gelişim geriliği olan çocuğa sahip annelerin küçük adımları uygulama becerilerini kazanmalarına etkisi. (Yayınlanmamış Doktora Tezi), Anadolu Üniversitesi, Eğitim Bilimleri Enstitüsü, Eskişehir.

Birleşmiş Milletler [BM] (2020). Politika notu: COVID-19 salgınının çocuklar üzerindeki etkileri. https://www.unicef.org/turkey/media/9881/file/COVID19\%20D\%C3\%B6neminin\%20\%C3\%87ocuklar \%20\%C3\%9Czerindeki\%20Etkilerine\%20\%C4\%BOli\%C5\%9Fkin\%20Politika\%20Notu.pdf (15 Eylül 2020)

Bozkurt, A. (2020). Koronavirüs (Covid-19) pandemi süreci ve pandemi sonrası dünyada eğitime yönelik değerlendirmeler: Yeni normal ve yeni eğitim paradigması. Açık Öğretim Uygulamaları ve Araştırmaları Dergisi (AUAd), 6(3), 112-142. https://dergipark.org.tr/en/download/articlefile/1215818

Creswell, J.W. (2016). Araştırma deseni. (M. Bütün, Çev.). Ankara: Eğiten Yayınclık.

Çetintepe S.P. ve Illhan M.N. (2020). COVID-19 Salgınında sağlık çalışanlarında risk azaltılması. J Biotechnol and Strategic Health Research, 1, 50-54.

Demirbilek, M. (2013). Zihinsel engelli bireylerin ve ailelerinin gereksinimleri. Turkish Journal of Family Medicine and Primary Care, 7(3), 58-64.

ECTA (Europen Communities Trade Mark Association, 2020). Equitably serving children with disabilities and their families during coronavirus (COVID-19). https://ectacenter.org/topics/disaster/coronavirus-equity.asp (8 Eylül 2020).

Göl-Güven, M., Şeker, V., Erbil, F., Özgünlü, M., Alvan, G. ve Uzunkök, B. (2020). Covid-19 pandemisinin aile yasantısına yansımaları rapor-2. https://www.researchgate.net/publication/343305552_Covid19_Pandemisinin_Aile_Yasantisina_Ya nsimalar Rapor-2 (28 Ağustos 2020).

Hodgetts, S., McConnell, D., Zwaigenbaum, L. \& Nicholas, D. (2014). The impact of autism services on mothers' occupational balance and participation. OTJR: Occupation, Participation and Health, 34(2), 81-93. doi:10.3928/15394492-20 130109-01

Howard, V., Williams, B. \& Lepper, C. (2010). Very young children with special needs: A foundation for educators, families and service providers (4. Ed.). Upper Saddle River, N.J: Pearson Education.

Huremović, D. (2019). Quarantine and Isolation. Effects on healthcare workers. In: Huremovic D Editors, Psychiatry of pandemics a mental health response to infection outbreak: a mental health response to infection outbreak. Springer Nature Switzerland AG. P. 119-125. doi:10.1007/978-3-030-15346-5. 
Demiröz, Yıldırım Parlak, Küçük Karahan \& Kayhan - Çukurova Üniversitesi Eğitim Fakültesi Dergisi, 50(2), 2021, 749-777

İmirlioğlu, i. (2009). Devlet hastanelerinde çalışan doktorların ve hemşirelerin stres kaynakları ve stresin performanslarına etkilerine ilişkin görüşleri (Ankara ili örneği). Verimlilik Dergisi, 2009(4), 53-101.

İzci, F. (2020). COVID-19 salgını ve sağılık çalışanları. Anatolian Journal of Psychiatry, 21(3), 335.

Kanık, N. (1993). Özürlü bebeklerin eğitimi ve aile katııımı. Ankara Üniversitesi Eğitim Bilimleri Fakültesi Özel Eğitim Dergisi, 1(3), 14-17.

Karadağ, G. (2014). Özel gereksinimi olan çocuğa sahip ebeveynlerin yaşadığı zorluklar ve çözüm önerileri. TAF Preventive Medicine Bulletin, 13(6), 491-494

Karahan, S. (2019). Okul öncesindeki özel gereksinimli çocukların sosyal becerilerine ilişkin anne, baba ve öğretmen görüşleri: Karma yöntem çalışması. (Yayınlanmamış yüksek lisans tezi), Hasan Kalyoncu Üniversitesi, Sosyal Bilimler Enstitüsü, Gaziantep.

Karahan, S., Demiröz, K., Yıldırım, Ş. ve Özaydın, L. (2020). Kovid-19 sürecinde özel gereksinimli çocuklar ile çalışan öğretmenlerin gereksinimlerinin belirlenmesi. International Conference on Covid-19 Studies, June 21-23, 2020, Ankara, Çevrimiçi (Online) Kongresinde sunulan bildiri. Ankara.

Mahoney, G. \& MacDonald, J. (2004). Responsive Teaching: Parent Mediated Developmental Intervention. Cleveland, $\mathrm{OH}$ : Case Western Reserve University.

McDuffie, A. \& Yoder, P. (2010). Types of parent verbal responsiveness that predict language in young children with autism spectrum disorder. Journal of Speech, Language and Hearing Research, 53(4), 1026-1039. doi: 10.1044/1092-4388(2009/09-0023)

Mereoiu, M., Abercrombie S. \& Murray, M. (2016). One step closer: connecting parents and teachers for improved student outcomes. Cogent Education, 3:1243079 http://dx.doi.org/10.1080/2331186X.2016.1243079

Miles, M, B. \& Huberman, A. M. (1994). Qualitative data analysis: An expanded Sourcebook. (2nd ed). Thousand Oaks, CA: Sage.

Milli Eğitim Bakanlığı Talim Terbiye Kurulu Başkanlığı. (2020). Salgın (Covid-19) sonrası okula uyum kılavuz ve etkinlikler. https://ttkb.meb.gov.tr/meb iys dosyalar/2020 08/28104730 okula uyum kilavuzu.pdf (5 Eylül 2020).

Munson, L. J. \& Odom, S. L. (1996). Review of rating scales that measure parent-infant interaction. Topics in Early Childhood Special Education, 16(1), 1-25.

Nakışci Kavas, B. ve Develi, A. (2020). Çalışma yaşamındaki sorunlar bağlamında covid-19 pandemisinin kadın sağlık çalışanları üzerindeki etkisi. Uluslararası Anadolu Sosyal Bilimler Dergisi, 4 (2), 84-112.

Olçay-Gül, S. (2014). Farklılaştırılmıs öğretim ve uyarlamalar. Ufuk Üniversitesi Sosyal Bilimler Dergisi, 3 , 111-123.

Orum-Çattık, E., Yetkin, A. İ. ve Diken, I. H. (2019). Erken çocukluk dönemi otizm spektrum bozukluğunda aile merkezli müdahaleler. Ankara Üniversitesi Eğitim Bilimleri Fakültesi Özel Eğitim Dergisi, Erken Görünüm. doi: 10.21565/ozelegitimdergisi.543446

Özbey, S. (2010). Okul öncesi çocuklarda uyum ve davranış problemleriyle başa çıkmada ailenin rolü. Aile ve Toplum, 11(6), 9-18.

Seven, M. (2020). COVID-19 salgını ve sonuçları açısından kadınların durumu. https://kockam.ku.edu.tr/covid-19-salgini-sonuclari-acisindan-kadinlarin-durumu-memnun-seven/ (19 Temmuz 2020).

Sönmez, N., Alptekin, S. ve Bıçak, B. (2018). Okul öncesi eğitim öğretmenlerinin kaynaştırma eğitiminde öz-yeterlik algıları ve hizmetiçi eğitim gereksinimleri: Bir karma yöntem çalışması. Abant izzet Baysal Üniversitesi Eğitim Fakültesi Dergisi, 18(4), 2270- 2297. doi: 10.17240/Aibuefd.2018.18.41844444422 
Demiröz, Yıldırım Parlak, Küçük Karahan \& Kayhan - Çukurova Üniversitesi Eğitim Fakültesi Dergisi, 50(2), 2021, 749-777

Toker, M., Başgül, Ş. ve Özaydın, L. (2019). Down sendromlu çocuğa sahip annelerin aile gereksinimlerinin belirlenmesi ve sosyal destek algılarına yönelik görüşleri. Ankara Üniversitesi Eğitim Bilimleri Fakültesi Özel Eğitim Dergisi, 20(4), 651-676.

Toy, A. ve Kesici, í. (2020). Özel gereksinimli çocuğu olan annelerin eğitim ihtiyaçları. Journal of Advanced Education Studies, 2 (1), 61-93.

UNC (The University of North Carolina at Chapel Hill ,2020). 2020 Impact report. https://fpg.unc.edu/covid-19-resources (19 Eylül 2020)

UNICEF (2020a). Özel gereksinimli çocuklar ve Covid-19. https://data.unicef.org/topic/childdisability/covid-19/ (19 Eylül 2020)

UNICEF (2020b). İşverenlerin Koronavirüs (COVID-19) salgını sırasında çalışan ebeveynlere destek olması için 7 öneri. https://www.unicef.org/turkey/hikayeler/işverenlerin-koronavirüs-covid-19-salgını sırasında çalışan-ebeveynlere-destek-olması (3 Eylül 2020)

UNICEF (2020c). COVID-19 bağlamında aile dostu politikalar ve diğer iyi işyeri uygulamaları: iş̧verenlerin atabileceği önemli adımlar. https://www.weps.org/sites/default/files/202006/Family\%20Friendly\%20Policies\%20COVID19_Turki sh_Final.pdf (3 Eylül 2020)

Yassıbaş, U. (2015). Otizm Spektrum Bozukluğu olan çocuğa sahip anne babaların yaşam deneyimlerine derinlemesine bakış. (Yayımlanmamış Yüksek lisans Tezi), Anadolu Üniversitesi Eğitim Bilimleri Enstitüsü, Eskişehir.

Yıldırım, Ş., Karahan, S., Demiröz, K., Şener Ö. ve Özaydın, L. (2020). Kovid-19 sürecinde özel gereksinimli çocukların ebeveynlerinin ihtiyaçları. International Conference on Covid-19 Studies, June 21-23, 2020, Ankara, Çevrimiçi(Online) Kongresi'nde sunulan bildiri. Ankara.

Yıldırım, Ş. ve Hacıfazlıoğlu, Ö. (2019). OSB tanısı almış çocuğu olan çalışan annelerin iş ve yaşam dengeleri. 29.Ulusal Özel Eğitim Kongresi, Kasım, 06-09, 2019, Kuşadası/Izzmir, Türkiye

Yıldırım, A. ve Şimşek, H. (2018). Sosyal bilimlerde nitel araştırma yöntemleri (11 Baskı), Ankara: Seçkin Yayıncilı.

Zeybekoğlu-Akbaş, Ö. ve Dursun, C. (2020). Koronavirüs (COVID-19) pandemisi sürecinde özel alanına kamusal alanı sığdıran çalışan anneler. Avrasya Sosyal ve Ekonomi Araştırmaları Dergisi (ASEAD), 7 (5), 78-94. 